\title{
Identification and Classification of Structural Soil Conservation Measures based on Very High Resolution Stereo Satellite Data
}

Authors: Sandra Eckert ${ }^{\mathrm{a} *}$ (sandra.eckert@cde.unibe.ch), Selamawit Tesfay Ghebremicael ${ }^{\mathrm{c}}$ (selamtesfay75@gmail.com), Hans Hurni ${ }^{\mathrm{a}, \mathrm{b}}$ (hans.hurni@cde.unibe.ch), Thomas Kohler ${ }^{\mathrm{a}}$ (thomas.kohler@cde.unibe.ch)

${ }^{a}$ Centre for Development and Environment, University of Bern, Hallerstrasse 10, CH-3012 Bern, Phone: +41316315439.

${ }^{\mathrm{b}}$ Department of Integrated Geography, Institute of Geography, University of Bern, Hallerstrasse 12, CH-3012 Bern, Phone: +41316318876.

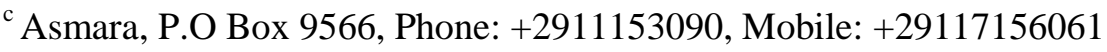

* Corresponding author

\begin{abstract}
Land degradation affects large areas of land around the globe, with grave consequences for those living off the land. Major efforts are being made to implement soil and water conservation measures that counteract soil erosion and help secure vital ecosystem services. However, where and to what extent such measures have been implemented is often not well documented. Knowledge about this could help to identify areas where soil and water conservation measures are successfully supporting sustainable land management, as well as areas requiring urgent rehabilitation of conservation structures such as terraces and bunds. This study explores the potential of the latest satellite-based remote sensing technology for use in assessing and monitoring the extent of existing soil and water conservation structures. We used a set of very high resolution stereo Geoeye-1 satellite data, from which we derived a detailed digital surface model as well as a set of other spectral, terrain, texture, and filtered information layers. We developed and applied an object-based classification approach, working on two segmentation levels. On the coarser level, the aim was to delimit certain landscape zones. Information about these landscape zones is useful in distinguishing different types of soil and water conservation structures, as each zone contains certain specific types of structures. On the finer
\end{abstract}


level, the goal was to extract and identify different types of linear soil and water conservation structures. The classification rules were based mainly on spectral, textural, shape, and topographic properties, and included object relationships. This approach enabled us to identify and separate from other classes the majority (78.5\%) of terraces and bunds, as well as most hillside terraces (81.25\%). Omission and commission errors are similar to those obtained by the few existing studies focusing on the same research objective but using different types of remotely sensed data. Based on our results, we estimate that the construction of the conservation structures in our study area in Eritrea required over 300,000 person-days of work, which underlines the huge efforts involved in soil and water conservation.

Keywords: Very high resolution images, Object-based image analysis, Digital surface model, Soil conservation, Agricultural terraces, Drylands

\section{Introduction}

Land degradation affects large areas of land around the globe. The world's drylands are especially vulnerable to degradation through inappropriate land use, climate change, or soil erosion (Schwilch et al. 2012; UNCCD 2014). The Central Highlands of Eritrea present a case in point: The effects of erratic rainfall, sloping terrain, and low vegetation cover, combined with unsustainable land management practices, lead to degradation of the land and its productive capacity. Soil erosion has been considered a key issue in natural resource management in the country since the 1970s (Herweg and Ludi, 1999; Hurni, 1978, Hurni, 1987, Hurni, 1993; Stillhardt et al., 2002). First countermeasures were taken by the government of Ethiopia, of which Eritrea was a province at that time; after Eritrea became independent in 1993, the Eritrean government continued these efforts with increased vigor (Bojö 1995; NEMP-E 1995). Soil and water conservation (SWC) measures are one way of counteracting soil erosion and combatting land degradation (WOCAT 2007). In Eritrea, investments in SWC flow predominantly into physical structures such as terraces and bunds. Aware of the 
negative effects of soil erosion as well as the rather unsustainable management and use of water, government authorities have systematically run large-scale campaigns to implement structural SWC measures, and many farmers have also established such measures on an individual basis.

But where exactly have these measures been established, and are they still being maintained? Knowing this would help to identify areas where structural SWC measures are successfully used to support sustainable land management, as well as areas requiring urgent rehabilitation of structures. However, there is no up-to-date and comprehensive documentation, let alone a spatially explicit one. Existing documentation is limited to a small number of local studies (Agnoletti et al., 2011; Gurtner et al. 2006). One example is a fieldwork-based, labor-intensive inventory conducted in 2006 that provides detailed qualitative and quantitative information for the area of Afdeyu, in Subzoba Serejeka of Zoba Maekel (Serejeka Sub-Region of Maekel Region) (Gurtner et al. 2006). This study achieved accurate results because it relied on the visual interpretation of aerial photography and very high resolution (VHR) satellite data combined with manual digitization of SWC structures. Such a method may be feasible if the study area is fairly small, but for larger areas it is too labor- and cost-intensive.

VHR satellite sensors launched in recent years achieve a spatial resolution of 0.3 to $0.5 \mathrm{~m}$, and aerial photography captured by means of unmanned aerial vehicles (UAVs) offers additional new options for mapping a variety of landscape elements, such as roads, buildings, tree lines, and hedges (Cheng and Han, 2016). However, the extraction of small objects and linear features is challenging (Quackenbush, 2004, Cheng and Han, 2016). Most techniques were developed to detect roads (Wang et al, 2016) and are semi-automatic or automatic (Quackenbush, 2004). Successful attempts to extract landscape elements typically involve a combination of algorithms, filters, and techniques. Spectral, textural, and shape properties are analyzed using mostly object-based classification approaches and, in some cases, techniques based on mathematical morphology (Aksoy et al. 2010; Sheeren et al. 2009). Some studies also included information from digital terrain and surface models (Bailly and Levavasseur, 2012; Tansey et al. 2009).

So far only very few studies have addressed the automatic identification of SWC structures such as stone terraces, stone walls, and stone or earth bunds (Diaz-Varela et al., 2014; Karydas et al., 2005; 
Mekuriaw et al., 2017) using latest VHR satellite data. Mekuriaw et al. (2017) attempted to extract terraces in the Ethiopian Highlands using satellite imagery downloaded from Google Earth and without including any surface or elevation information. The imagery was limited in terms of spectral information and spatial resolution. They achieved moderate to acceptable results. By contrast, DiazVarela et al. (2014) used aerial photographs and a digital surface model captured by a UAV that both had an extremely high resolution $(0.1 \mathrm{~m})$, and for their very small test area of 120 ha achieved highly accurate results. In the present study, we aimed to combine some of the advantages of these two previous studies by exploring the potential of an original remotely sensed stereo VHR satellite data set of the highest spatial resolution available at the time. Using a data set captured in stereo would enable us to generate a detailed digital surface model to be included in the analysis. The overall goal of our study was to develop a method to identify and quantify structural SWC measures implemented in Eritrea, based on VHR optical satellite data. The intended future purpose of the method was to generate comprehensive, up-to-date, and spatially explicit knowledge about SWC efforts throughout Eritrea's Central Highlands. The specific objectives of the study, therefore, were (a) to develop a classification approach that makes it possible to classify linear SWC structures and determine where they have been implemented; (b) to extract linear SWC structures and estimate their total length; and (c) to identify areas where hillside terraces have been installed.

\section{Study Area and Soil Conservation Measures}

The study area of $23.3 \mathrm{~km}^{2}$ is located north of Asmara, in the Central Highlands of Eritrea, within Zoba Maekel (Maekel Region), between $38.85^{\circ}$ and $38.91^{\circ} \mathrm{N}$ latitude and $15.51^{\circ}$ and $15.48^{\circ} \mathrm{E}$ longitude. Its altitude ranges between 2342 and $2559 \mathrm{~m}$ a.s.l. A detailed description of the area was provided by Gurtner et al (2006). It is summarized in what follows, and complemented with information from other studies. The catchments consist predominantly of gently rounded hills, interspersed with relatively flat-bottomed valleys. The climate is semi-arid. The rainfall pattern is sporadic and highly variable in both temporal and spatial terms. High-intensity rainfall events are common and cause heavy runoff, flooding, and soil erosion. Annual rainfall records in the study area 
measured between 1985 and 1998 show a maximum of 658 mm (1995) and a minimum of 259 mm (1989). The mean annual rainfall is $458 \mathrm{~mm}$. The mean annual temperature in the area is $18.4{ }^{\circ} \mathrm{C}$, with an average monthly maximum of $26.5^{\circ} \mathrm{C}$ and an average monthly minimum of $9.2^{\circ} \mathrm{C}$, respectively (Gurtner et al. 2006; Stillhardt et al.,2002).

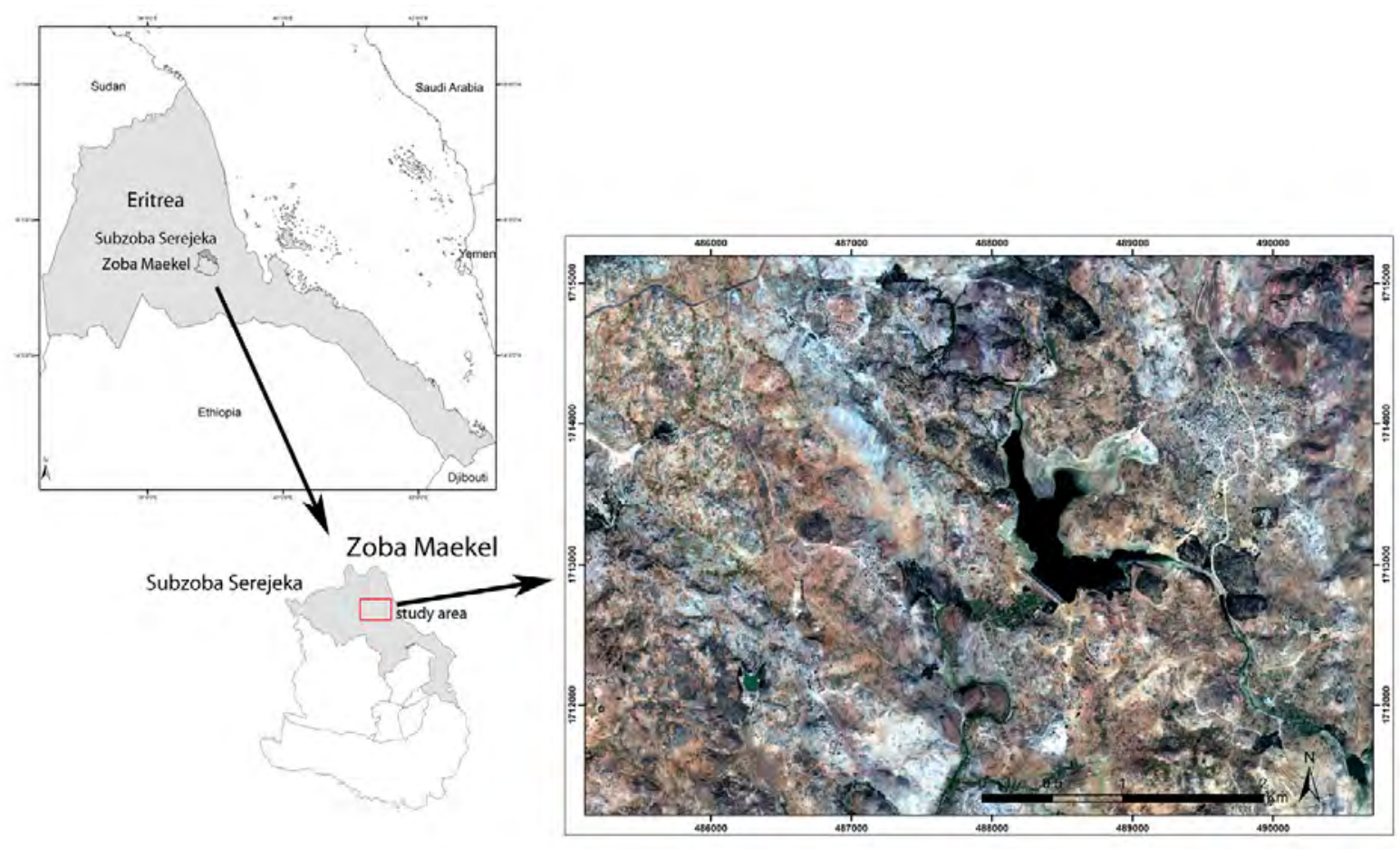

Figure 1: Overview map of the study area located in the Central Highlands of Eritrea, in Subzoba Serejeka (highlighted in gray) of Zoba Maekel.

As Figure 1 shows, the study area is practically devoid of forest, with the present forest cover estimated at 1\% or less (NEMP-E 1995). Remaining native trees and shrubs are confined to the immediate surroundings of churches and few traditionally enclosed areas (Gurtner et al. 2006). In addition, there are several small afforestation areas that were planted mainly with Eucalyptus during the Italian colonial period. This situation is typical for large sections of the Highlands today. Many Eritreans, including policymakers, believe that forests were much larger in the past, covering about $30 \%$ of the Highlands around 1900. However, there is growing evidence that this figure is too high, 
and that large-scale deforestation must have occurred earlier, if at all (Boerma 2006, Nyssen et al. 2009). According to the General Soil Map of Eritrea (FAO 1998), the dominant soil type in the study area is stony cambisol. On ridges, cambisols are associated with lithosols (now grouped under leptosols), and on valley floors, with fluvisols (Bosshart 1997, in Stillhardt et al. 2002, adapted; Gurtner et al. 2006). The study area is characterized by small-scale subsistence farming. Land use is mixed, including both crop and livestock production. Cropland covers about $70 \%$ of the study area and is mostly rainfed. The climatic conditions tend to limit crop growth to the main rainy season (June through September). Traditionally, the main crops in the area are cereals (wheat and barley). Crop failure is common during the small rainy season, the shortage and irregularity of rainfalls being one of the main limitations aside from low soil fertility. Cash crops such as onions, tomatoes, and potatoes are grown on fertile, well-managed terraces close to the village, as well as on a small number of irrigated fields (Gurtner et al. 2006). Crops are grown in rotation, with a fallow period every four years, which means that one-quarter of the cropland is under fallow each year (Gurtner et al. 2006; Woldetensae et al. 2005). Land shortage due to population growth has forced farmers to extend cultivation to marginal areas with steeper slopes and shallow soils. Land is generally overused, nutrients and organic matter are insufficiently replaced, and loss of topsoil through soil erosion is high (Gurtner et al. 2006; Stillhardt et al. 2002). During long periods throughout the year there is no protective vegetation cover, which is particularly problematic at the beginning of the rainy season. Farmers are aware of land degradation. A range of indigenous and introduced SWC practices have been implemented. Their importance has been recognized long ago: indigenous SWC structures, such as high stone terraces, constructed without the use of levelling instruments and not exactly along the contour, have been in use for generations (Gurtner et al. 2006). During the Italian colonial period, tree and sisal fence planting activities were promoted, and farmers were forced by law to establish terraces, especially on steeper slopes. From the mid-1970s onwards, when Eritrea formed part of Ethiopia, the authorities intensified SWC activities by means of food-for-work campaigns with substantive international funding (Hurni 1990). These efforts were continued and extended across the country after Eritrea's independence in 1993, still organized in the form of food-for-work or cash-forwork mass campaigns. Funding for these campaigns came from the Eritrean government as well as 
international sources (Gurtner et al. 2006). Although indigenous SWC measures were retained as much as possible, efforts concentrated on introduced measures: stone and earth bunds, grass strips, tied ridges, check dams, hillside terracing and tree planting on steep slopes, and permanent area enclosures were implemented throughout the country. Overall, the study area has received much attention with regard to SWC and is among the country's best-conserved areas.

This study focuses on structural SWC measures on cropland - stone terraces, stone walls, and stone and earth bunds (Figure 2A-C) - as well as hillside terraces (Figure 2D). Their spatial characteristics are described in Table 1.
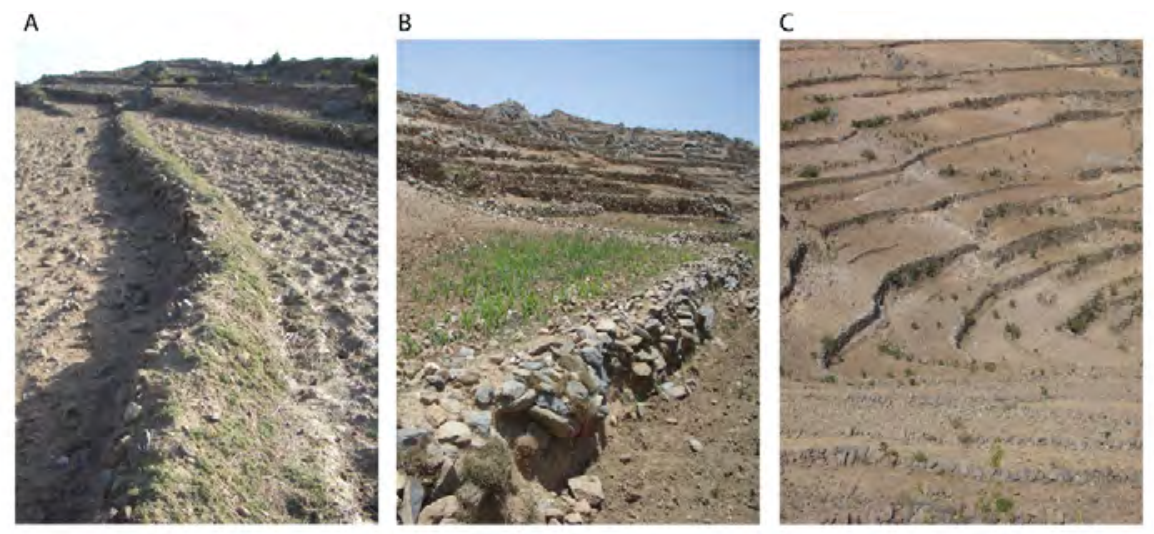

D

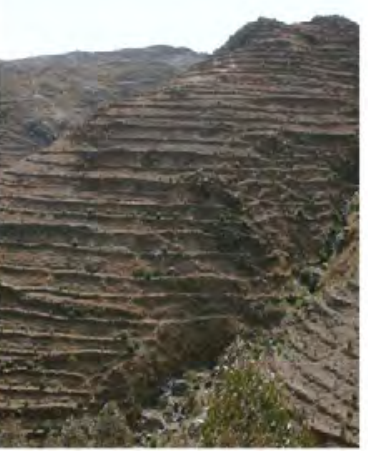

Figure 2: The different SWC structures implemented in the study area and across much of the Eritrean Highlands: earth bunds (A), stone walls (B), stone terraces (C), and hillside terraces (D). (Photos by M. Gurtner)

\begin{tabular}{|c|c|c|c|c|}
\hline SWC measure & Purpose & Appearance and spacing & Height (m) & Width (m) \\
\hline Stone terrace & $\begin{array}{c}\text { Increase arable land, } \\
\text { reduce runoff, control } \\
\text { erosion, conserve } \\
\text { moisture, increase soil } \\
\text { fertility }\end{array}$ & $\begin{array}{c}\text { Spacing varies according } \\
\text { to slope, soil depth, soil } \\
\text { fertility, and expected } \\
\text { runoff; narrow on steep } \\
\text { slopes }\end{array}$ & $1.0-5.0$ & $1.0-1.5$ \\
\hline \multirow{2}{*}{$\begin{array}{c}\text { Stone and earth } \\
\text { bund }\end{array}$} & $\begin{array}{c}\text { Trap and reduce } \\
\text { runoff, increase } \\
\text { infiltration, reduce } \\
\text { siltation of dams } \\
\text { downstream, regulate }\end{array}$ & $\begin{array}{c}\text { Applied on slopes with a } \\
\text { gradient of 3-50\%; spacing } \\
\text { is around 10 m on gentle } \\
\text { slopes and narrower in } \\
\text { steeper areas and flood- }\end{array}$ & 0.3-0.75 & 0.5 \\
\hline
\end{tabular}




\begin{tabular}{|c|c|c|c|c|}
\hline & runoff & $\begin{array}{c}\text { prone areas; the vertical } \\
\text { interval between bunds is } \\
1 \mathrm{~m} \text { on slopes }<15 \% \text { and } \\
2.5 \times \text { the depth of the } \\
\text { arable soil layer on slopes } \\
>15 \%\end{array}$ & & \\
\hline Hillside terrace & $\begin{array}{l}\text { Retain sediments and } \\
\text { runoff, conserve } \\
\text { water, provide a level } \\
\text { platform for tree } \\
\text { growth, including for } \\
\text { re- and afforestation }\end{array}$ & $\begin{array}{c}\text { The spacing between } \\
\text { structures is } 2-5 \mathrm{~m} \text {, i.e. } \\
\text { narrower than for stone } \\
\text { and earth bunds; applied } \\
\text { in mountainous areas with } \\
\text { slopes }>30 \%\end{array}$ & 0.75 & 1.0 \\
\hline $\begin{array}{l}\text { Afforestation and } \\
\text { area enclosure in } \\
\text { steep slopes }\end{array}$ & $\begin{array}{l}\text { Enable vegetation } \\
\text { regeneration and } \\
\text { improvement of soil } \\
\text { cover, wood } \\
\text { production, and } \\
\text { fodder production; } \\
\text { reduce runoff and soil } \\
\text { erosion, prevent } \\
\text { downstream dam } \\
\text { siltation }\end{array}$ & $\begin{array}{l}\text { The spacing between trees } \\
\text { is } 2-2.5 \mathrm{~m} \text {; trees are } \\
\text { planted on hillside } \\
\text { terraces, contour bunds, } \\
\text { and check dams, as well as } \\
\text { in microbasins }\end{array}$ & -- & -- \\
\hline
\end{tabular}

Table 1: Characteristics of the SWC measures focused on in this study. (Source: Gurtner et al. 2006)

The different types of indigenous and introduced SWC structures on cropland occur in complex combinations within the same conservation unit (e.g. Negassi et al. 2002; Ogbazghi et al., 2011), and all appear as linear features in the satellite image. Accordingly, we do not distinguish between the different types of structures, subsuming them under "terraces and bunds on cropland”. Hillside terraces (Figure 2D) are found exclusively on uncultivated steep slopes and are frequently afforested. They were first introduced to the study area in the 1970s to prevent erosion and runoff onto adjacent cropland and into reservoirs supplying water for domestic use and small-scale irrigation (Gurtner et al. 2006). In the satellite image, terraced hillsides appear as a composite of linear and non-linear features, with spectral characteristics of dense vegetation if they are covered with forest.

\section{Materials and Methods}

\subsection{Data Sets and Satellite Data Processing}


For the purpose of this study we acquired a standard geometrically corrected and already pansharpened multispectral 4-band - blue, green, red, near-infrared (NIR) - stereo data set of GeoEye-1 with a geometric resolution of $0.5 \mathrm{~m}$. Seasonality plays an important role in the performance of SWC structure detection algorithms. This was also observed by Mekuriaw et al. (2017) in a study done in an area with similar land cover and land use in Ethiopia. Before the harvest, most SWC structures are covered by mature crops and are therefore not visible. Consequently, data acquisition for the present study was scheduled to take place after the harvest season, which lasts from September to early November. The data were captured in reverse scan mode on 22 November 2013. Table 2 indicates the acquisition parameters of the two scenes.

\begin{tabular}{|l|c|c|}
\hline Characteristics (deg) & Data Set 1 & Data Set 2 \\
\hline Sensor Azimuth & 62.7907 & 148.2522 \\
\hline Sensor Elevation & 64.46547 & 61.48097 \\
\hline Sun Angle Azimuth & 151.2241 & 151.5521 \\
\hline Sun Angle Elevation & 49.54689 & 49.66311 \\
\hline
\end{tabular}

Table 2: Acquisition parameters of the GeoEye-1 stereo pair.

The multispectral stereo data set was orthorectified and a digital surface model (DSM) was generated using the PCI Geomatica 2014 software (PCI Geomatics, Richmond Hill, Ontario, Canada). Among other things, this software provides a third-order 3D rational functions model developed by Grodecki and Dial (2003). In addition to the rational polynomial coefficients (RPCs) delivered by the satellite data provider, we included seven differentially measured GPS points - so-called ground control points (GCPs) - to refine the zero-order polynomial adjustment (RPC0). We only considered GCPs whose root mean square error (RMSE) in both the $\mathrm{x}$ - and the $\mathrm{y}$-direction were smaller than one pixel. After creating epipolar images, we performed an area-based matching, selecting the "high level of detail” 
setting and a matching/sampling interval of 2 (pixels). This resulted in a DSM with a geometric resolution of $1.0 \mathrm{~m}$. We were unable to measure additional independent GCPs due to limited accessibility linked to the sensitivity of collecting georeferenced data in Eritrea. For this reason, we compared the GCP elevation values of the available GCPs with the elevation values of the generated DSM in order to approximate the absolute accuracy of the generated DSM.

Once this was done, we calculated a number of spectral and textural measures from the orthorectified multispectral data and derived several terrain parameters from the generated DSM. All of these derivatives are listed and described in Table 3.

\begin{tabular}{|c|c|c|}
\hline \multicolumn{3}{|c|}{ Data sets } \\
\hline \multicolumn{3}{|c|}{ GeoEye-1: 4 bands } \\
\hline \multicolumn{3}{|c|}{ DSM } \\
\hline \multicolumn{3}{|c|}{ Digitized roads } \\
\hline Data set derivatives & Definition and settings & References \\
\hline NDVI & $(N I R-R E D) /(N I R+R E D)$ & Rouse et al. (1973) \\
\hline GLCM texture: Angular Second Moment & Window size: $5 \times 5$; step 2 & Haralick et al. (1973) \\
\hline GLCM texture: Dissimilarity & Window size: $5 \times 5$; step 2 & Haralick et al. (1973) \\
\hline GLCM texture: Homogeneity & Window size: $5 \times 5$; step 2 & Haralick et al. (1973) \\
\hline PanTex & $\begin{array}{c}\text { Resampling to } 2 \text {-m pixel resolution; } \\
\text { GLCM texture: } \text { Contrast; window } \\
\text { size: } 7 \times 7\end{array}$ & Pesaresi et al. (2008) \\
\hline \multicolumn{3}{|l|}{ Slope } \\
\hline \multicolumn{3}{|l|}{ Aspect } \\
\hline \multicolumn{3}{|l|}{ Curvature } \\
\hline DifMin & $\begin{array}{c}\text { DifMin }=h_{i} / h_{\min } \\
h_{i}=\text { DSM value for the target pixel; } \\
h_{\min }=\text { minimum DSM value for a } \\
\text { given neighborhood of } 6 \text { m around } \\
\text { the target pixel }\end{array}$ & McNab (1989) \\
\hline Toplndex & $\begin{array}{c}\text { Toplndex }=h_{i} / h_{\text {ave }} \\
h_{i}=\text { DSM value for the target pixel; } \\
h_{\text {ave }}=\text { average DSM value for a } \\
\text { given neighborhood of } 6 \text { m around } \\
\text { the target pixel }\end{array}$ & McNab (1989) \\
\hline CannyRED & $\begin{array}{c}\text { Canny edge detection filter } \\
\text { (gradient direction) for RED band; } \\
\text { window size: } 5 \times 5\end{array}$ & Canny (1986) \\
\hline CannyDSM & $\begin{array}{l}\text { Canny edge detection filter } \\
\text { (gradient direction) for DSM; } \\
\text { window size: } 5 \times 5\end{array}$ & Canny (1986) \\
\hline
\end{tabular}


Table 3: Description of all spatial data sets used in the object-based classification. GLCM = gray-level co-occurrence matrix.

The anisotropic rotation-invariant built-up presence index (PanTex) (Pesaresi et al. 2008) was calculated to delineate urban and non-urban regions. The main component of the PanTex workflow computes the contrast textural statistic based on the gray-level co-occurrence matrix (GLCM) as introduced by Haralick et al. (1973). It uses different displacement vectors to compute the contrast statistic to take advantage of urban textures’ anisotropic nature. The directional components of the contrast statistic are used to produce a single texture layer using the intersection and union operators. The result provides structural information on urban regions, including buildings, open spaces, and, partially, roads (Pesaresi et al. 2008). This method has been shown to be highly efficient in delineating built-up areas based on optical satellite data (Pesaresi et al. 2008; Zeug and Eckert, 2010). Besides slope, aspect, and curvature, we calculated the difference from the minimum value (DifMin) in a defined circle around the target pixel and the topographic position index (TopIndex). Both indices are based on the concepts developed by McNab (1989). They were successfully applied by DiazVarela et al. (2014) in a study with goals similar to those of our study. Finally, we filtered the red band and the DSM using a Canny edge detector filter (Canny, 1986). In addition to the data sets and derivatives described here, we used a layer of digitized roads, which we digitized manually based on the Geoeye- 1 satellite data. All data sets and derivatives listed in Table 3 were used for the differentiation and classification of the various SWC structures (see Section 3.2). The data sets and derivatives were calculated prior to the object-based image analysis (OBIA) in order to keep the object-based classification approach computationally light.

\subsection{Object-Based Classification}


OBIA is a methodological approach that has gained popularity with the increasing spatial resolution of remotely sensed satellite data (Hay et al., 2001; Blaschke and Strobl, 2001; Blaschke et al., 2004; Blaschke, 2010). In this approach, similar pixels are clustered into meaningful objects before being classified. This makes it possible to analyze shape features as well as neighborhood relationships and context information (on the same and across multiple segmentation scales) and to integrate them into the classification process (Benz et al., 2004; Blaschke et al., 2000; Blaschke et al., 2004; Blaschke, Lang and Hay, 2008; Blaschke, 2010). In this way, the method enables the classification of complex relationships between image objects - in our case, objects representing a variety of landscape elements - and thereby overcomes the limitations of conventional pixel-based image classification methods. OBIA has also been successfully applied to land cover and land use mapping (Benz et al., 2004; Blaschke et al., 2004; Blaschke et al., 2008; Blaschke, 2010).

In this study we performed OBIA using the eCognition Developer 8.9 software (Trimble Geospatial Imaging). Detailed information on the functionalities and concepts can be found in Baatz and Schäpe (2000), Flanders et al. (2003), and Benz et al. (2004). First, we performed a multiresolution segmentation, in which clusters of pixels with similar spectral properties are iteratively aggregated so as to minimize heterogeneity (Benz et al. 2004). The user controls the segmentation algorithm by setting scale and homogeneity parameters. The algorithm can be applied on multiple scales (also referred to as segmentation levels), resulting in a hierarchical network of segments. Such a procedure is particularly suitable for the classification of VHR image data, in which meaningful objects (e.g. a tree or a mixed forest) consist of several pixels (e.g. branches and leaves, or broad- and needle-leaved trees). As mentioned above, it enables the integration into the classification process of statistical and textural parameters, as well as information about objects' shape, extent, size, and topological relationships to neighboring objects or objects on a sub- or super-level. This can be very useful for classifying meaningful linear objects.

We performed multiresolution segmentation on two hierarchical levels. On the finer Level 1, the main goal was to extract and identify different types of linear SWC structures. On the coarser Level 2, the aim was to delimit certain landscape zones, with a focus on distinguishing steep slopes with hillside 
terraces from agricultural land with terraces and bunds on gently sloping cropland, on the one hand, and from irrigated land mainly cultivated with vegetables in flat valley bottoms, on the other.

Information about these landscape zones is useful in distinguishing different types of SWC structures, as each zone contains certain specific types of structures.

For both segmentation processes we used a combination of spectral information and information on local differences in the height of objects. More specifically, we used all four multispectral bands, DifMin, TopIndex, CannyRED and CannyDSM (see Table 3). On Level 1, we weighted the four multispectral bands by 1, whereas DifMin and TopIndex were weighted by 0.7 and CannyRED and CannyDSM by 0.5. On Level 2, we largely used the same weighting, the only difference being an increase in the weights of CannyRED and CannyDSM to 0.8 to achieve improved delineation along linear structures. The homogeneity criterions 'shape' and 'compactness' were set to 0.6 and 0.8 , respectively, for both levels. On Level 1, this resulted in segments delineating single landscape objects such as trees, bushes, buildings, grass strips, stone and earth bunds, walls, terraces, shadows caused by terraces, and others, whereas on Level 2 the segments delineate landscape zones characterized mainly by their land cover and land use. The segmentation parameters were determined visually based on the first author's expertise. After segmentation, a large number of spectral, textural, shape, and topographic features were calculated for each object. 


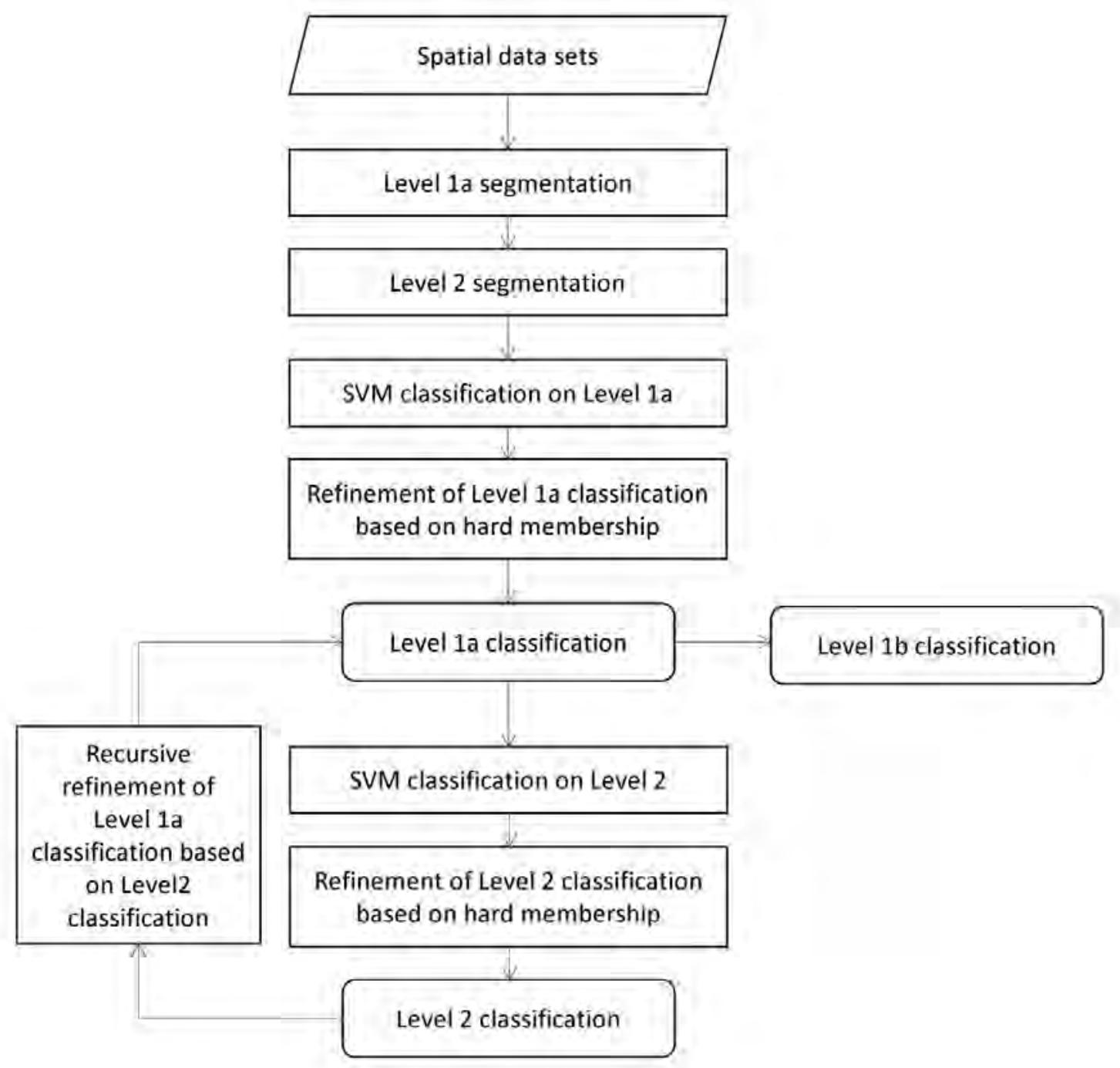

Figure 3: Flow chart of the developed classification approach. 


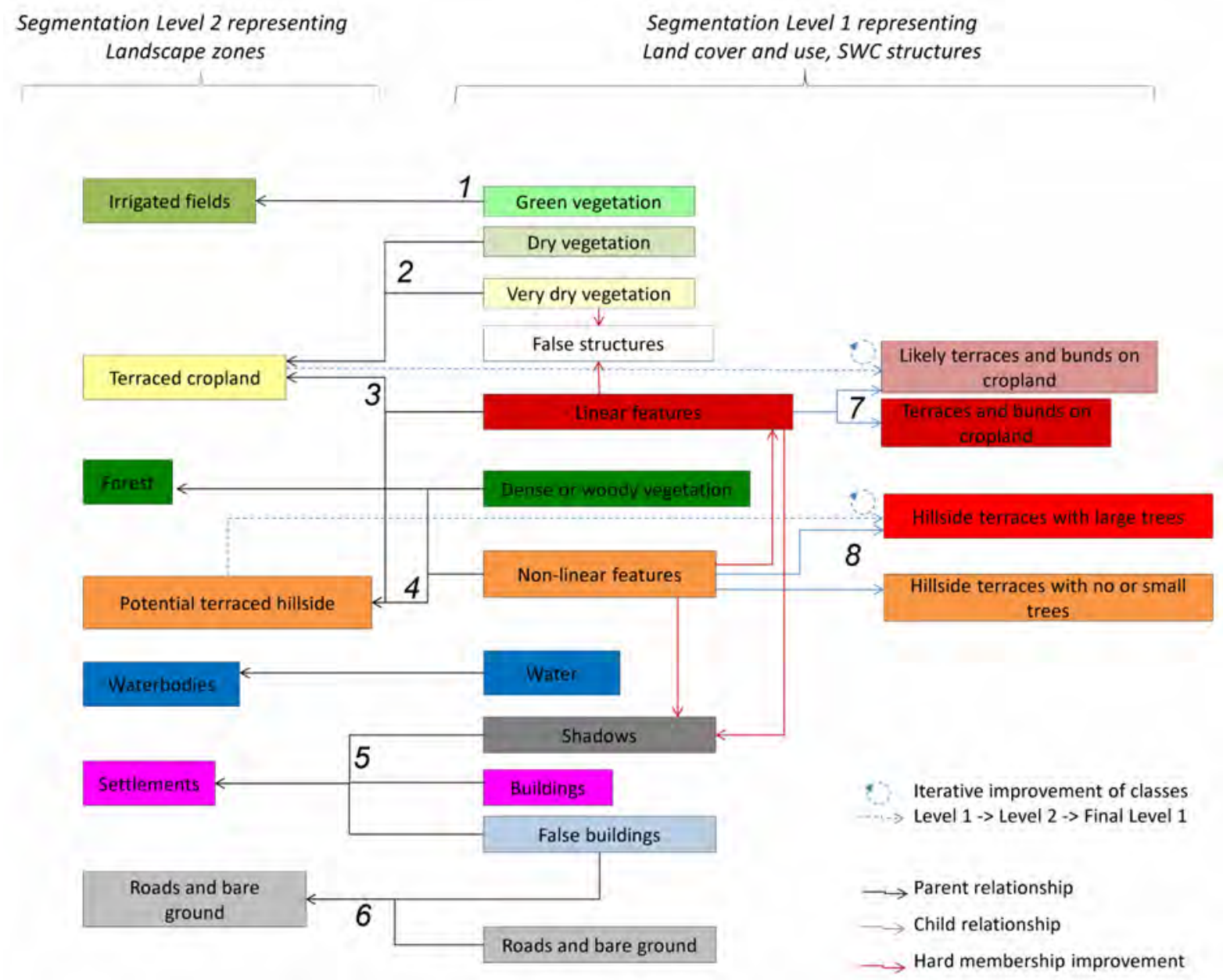

Figure 4: Class hierarchy and iterative process of class refinement and classification improvement.

Figure 3 shows a flow chart of the iterative classification approach developed. After the segmentation of both levels we began with the preliminary classification of objects on Level 1, first defining the classes (see Figure 4 for the classes defined on each segmentation level) and selecting representative samples. We opted for a support vector machine (SVM) classifier with a linear kernel and C $=2$ (Vapnik, 2000). This is one of the most popular machine learning algorithms (Chen and Han, 2016), and various multiscale OBIA studies have highlighted the superiority of non-parametric machine learning classifiers such as random forest and SVM over parametric statistical classifiers (e.g. maximum likelihood) or heuristically simple classifiers (e.g. k-nearest neighbor) in classifying both land cover and land use (Duro et al., 2012; Gosh and Joshi, 2014; Kaszta et al., 2016; Petropoulos et al., 2012) as well as specific landscape elements (Das et al., 2011; Huang and Zhang, 2009; Heinzel 
and Koch, 2012; Song and Civco, 2004). The calculation and selection of appropriate features for the object-based classification was based on past research findings (Andrini, D., 2011; Diaz-Varela et al., 2014; Mekuriaw, 2017; Zeug and Eckert, 2010), statistical and visual inspection of all calculated features, and examination of the separability of the defined SWC structure classes. The features that were used in the SVM classifier are indicated in the top row and last column of Table 4. Next, we refined the resulting classification by applying a sequence of hard membership functions based on shape, spectral, textural, and neighborhood characteristics (indicated in the second row of Table 4). In order to further improve the classification, we then introduced Level 2 representing landscape zones (i.e. steep hillside terraces, gently sloping cropland, and irrigated vegetable gardens in the humid valley bottoms). Classification on this level followed the same strategy used on Level 1: SVM classification, followed by refinement of the resulting classification based on hard membership functions.

The classes thus defined are presented in Figure 4, which illustrates the class hierarchy on the two segmentation levels that we defined for our study. Figure 4 also shows which classes were iteratively refined and improved by (a) working on two segmentation levels and (b) introducing hardmembership class assignments.

After classification of the landscape zones on Level 2 we were able to refine the classification on Level 1, based on the fact that some of the classes identified on this level only exist in certain landscape zones. This was the case for the classes labelled 1, 2, 4, 5, and 6 in Figure 4. Once we had achieved an optimized classification result on Level 1, we then further subdivided the two classes Linear features and Non-linear features (labels 7 and 8 in Figure 4) based on the landscape zonation performed on Level 2 (labelled 3 and 4). More specifically, Potential terraced hillsides were split up into Hillside terraces with no or small trees (probably afforested only recently, although the small size of the trees might also have other reasons, such as unfavorable growth conditions) and Hillside terraces with large trees (probably afforested earlier and already densely covered). We deliberately chose not to differentiate between young and old hillside terraces, as information about the age of terraces cannot be derived directly from VHR satellite data; all we can derive directly is the size and 
density of tree coverage. Linear features were split up into a class of clearly identifiable terraces, walls, and bunds, called Terraces and bunds on cropland, and a class of structures that might be terraces but are either not clearly visible, have collapsed, or are covered in vegetation, called Likely terraces and bunds on cropland. Once the class hierarchy was sufficiently refined and led to satisfactory results, the whole classification rule-set was run in its entirety, resulting in the final classification. This was then validated by means of an accuracy assessment.

\begin{tabular}{|c|c|c|c|c|}
\hline $\begin{array}{l}\text { Classification } \\
\text { steps }\end{array}$ & Class & Hard membership feature & New class assigned & $\begin{array}{l}\text { Features used for SVM } \\
\text { classification }\end{array}$ \\
\hline $\begin{array}{l}\text { Level 1, SVM } \\
\text { classification }\end{array}$ & All level 1 classes & & & $\begin{array}{l}\text { Statistical features based on } \\
\text { input data: mean and standard } \\
\text { deviation of all data sets and } \\
\text { derivatives. } \\
\text { Shape features: asymmetry, } \\
\text { border index, compactness, } \\
\text { density, elliptic fit, rectangular } \\
\text { fit, roundness, shape index }\end{array}$ \\
\hline \multirow{11}{*}{$\begin{array}{l}\text { Level 1, } \\
\text { refinement } \\
\text { based on hard } \\
\text { membership }\end{array}$} & All level 1 classes & (mean digitized roads $<165$ ) & $\begin{array}{l}\text { Roads and bare } \\
\text { ground }\end{array}$ & \\
\hline & Buildings & (mean PanTex $<130$ ) & False buildings & \\
\hline & $\begin{array}{l}\text { Dense or woody } \\
\text { vegetation }\end{array}$ & (mean PanTex < 290) & Shadows & \\
\hline & Waterbodies & $\begin{array}{l}\text { (border to dense or woody } \\
\text { vegetation }>6 \mathrm{px} \text { and border } \\
\text { to waterbodies }<2 \mathrm{px} \text { ) }\end{array}$ & $\begin{array}{l}\text { Dense or woody } \\
\text { vegetation }\end{array}$ & \\
\hline & Waterbodies & $\begin{array}{l}\text { (border to shadow }>6 \mathrm{px} \text { and } \\
\text { border to waterbodies }<2 \mathrm{px} \text { ) }\end{array}$ & Shadows & \\
\hline & Waterbodies & $\begin{array}{l}\text { (border to roads and bare } \\
\text { ground }>6 \mathrm{px} \text { and border to } \\
\text { waterbodies }<2 \mathrm{px} \text { ) }\end{array}$ & $\begin{array}{l}\text { Roads and bare } \\
\text { ground }\end{array}$ & \\
\hline & Non-linear features & (asymmetry < 0.85) & Non-linear features & \\
\hline & $\begin{array}{l}\text { Linear features } \\
\text { Non-linear features } \\
\text { False structures }\end{array}$ & (mean NIR < 290) & Shadows & \\
\hline & $\begin{array}{l}\text { Linear features } \\
\text { Non-linear features } \\
\text { False structures }\end{array}$ & (border to buildings $\geq 1 \mathrm{px}$ ) & False structures & \\
\hline & $\begin{array}{l}\text { Dense or woody } \\
\text { vegetation } \\
\text { Green vegetation }\end{array}$ & $\begin{array}{l}\text { (mode }[\min . \text { slope }]>0.1 \text { and } \\
\text { mode }[\text { min. slope }]<1.4 \text { ) }\end{array}$ & Green vegetation & \\
\hline & Linear features & $\begin{array}{l}\text { (border to roads and bare } \\
\text { ground } \geq 1 \mathrm{px} \text { ) }\end{array}$ & False structures & \\
\hline
\end{tabular}




\begin{tabular}{|c|c|c|c|c|}
\hline $\begin{array}{l}\text { Level 2, SVM } \\
\text { classification }\end{array}$ & All level 2 classes & & & $\begin{array}{l}\text { Statistical features based on } \\
\text { input data: mean, standard } \\
\text { deviation, and skewness of all } \\
\text { data sets and derivatives, } \\
\text { mode[max. PanTex], } \\
\text { mode[min. slope], mode[max. } \\
\text { slope], mode[min. DifMin]. } \\
\text { Shape features: asymmetry, } \\
\text { border index, compactness, } \\
\text { density, elliptic fit, rectangular } \\
\text { fit, roundness, shape index, } \\
\text { radius of largest/smallest } \\
\text { enclosing ellipse. } \\
\text { Class-related features, relations } \\
\text { to sub-objects: relative area of } \\
\text { classes in Level } 1 . \\
\text { Customized feature: Stdev of } \\
\text { border contrast on Level } 1 .\end{array}$ \\
\hline \multirow{6}{*}{$\begin{array}{l}\text { Level 2, } \\
\text { refinement } \\
\text { based on hard } \\
\text { membership }\end{array}$} & Waterbodies & $\begin{array}{l}\text { (existence of waterbodies } \\
\text { sub-object }=0 \text { ) }\end{array}$ & Forests & \\
\hline & Settlements & $\begin{array}{l}\text { (relative area of buildings } \\
\text { sub-objects }<0.06 \text { ) }\end{array}$ & Terraced cropland & \\
\hline & Forest & (border index > 2.7) & Terraced cropland & \\
\hline & Roads and bare ground & $\begin{array}{l}\text { (relative area of linear } \\
\text { features sub-objects }>0.17 \\
\text { and relative border to } \\
\text { potential terraced hillsides }> \\
0.3 \text { ) }\end{array}$ & Terraced cropland & \\
\hline & Roads and bare ground & $\begin{array}{l}\text { (relative border to } \\
\text { settlements }>0.1 \text { ) }\end{array}$ & Settlements & \\
\hline & $\begin{array}{l}\text { Terraced cropland } \\
\text { Potential terraced } \\
\text { hillsides } \\
\text { Roads and bare ground }\end{array}$ & (mean digitized roads < 220) & $\begin{array}{l}\text { Roads and bare } \\
\text { ground }\end{array}$ & \\
\hline \multirow{5}{*}{$\begin{array}{l}\text { Final Level } 1 \\
\text { classification } \\
\text { based on } \\
\text { optimized } \\
\text { Level } 1 \text { \& } \\
\text { Level } 2 \\
\text { classification }\end{array}$} & $\begin{array}{l}\text { Forest } \\
\text { Potential terraced } \\
\text { hillsides } \\
\text { Linear features } \\
\text { Non-linear features } \\
\end{array}$ & $\begin{array}{l}\text { (existence of potential } \\
\text { terraced hillsides super- } \\
\text { object =1) }\end{array}$ & $\begin{array}{l}\text { Hillside terraces } \\
\text { with no or small } \\
\text { trees }\end{array}$ & \\
\hline & $\begin{array}{l}\text { Forest } \\
\text { Potential terraced } \\
\text { hillsides } \\
\text { Linear features } \\
\text { Non-linear features } \\
\end{array}$ & $\begin{array}{l}\text { (existence of forest super- } \\
\text { object = 1) }\end{array}$ & $\begin{array}{l}\text { Hillside terraces } \\
\text { with large trees }\end{array}$ & \\
\hline & Linear features & $\begin{array}{l}\text { (mean difference to } \\
\text { neighboring segments' } \\
\text { CannyRED }<200 \text { ) }\end{array}$ & $\begin{array}{l}\text { Likely terraces and } \\
\text { bunds on cropland }\end{array}$ & \\
\hline & $\begin{array}{l}\text { Linear features } \\
\text { Non-linear features }\end{array}$ & $\begin{array}{l}\text { (existence of settlements } \\
\text { super-object =1) }\end{array}$ & False structures & \\
\hline & $\begin{array}{l}\text { Likely terraces and bunds } \\
\text { on cropland }\end{array}$ & (length/width > 4.2) & $\begin{array}{l}\text { Terraces and bunds } \\
\text { on cropland }\end{array}$ & \\
\hline
\end{tabular}

Table 4: Characteristic features, object properties, and thresholds used for the classification of SWC structures. 


\subsection{Accuracy Assessment of Soil and Water Conservation Measure Classification}

Since our focus was on the correct classification and quantification of terraces and bunds on cropland and the correct identification of hillside terraces, the accuracy assessment was conducted exclusively for these two types of SWC structures classified into the four final subclasses on Level 1. We assessed the classification accuracy in quantitative terms by comparing the classification results in eight randomly selected subsets within the study area to ground truth data. To obtain ground truth data, a person who had not been involved in the classification process digitized SWC structures based on the Geoeye-1 satellite image. Terraces and bunds on cropland were digitized as linear polylines, whereas afforested and non-forested hillside terraces we digitized as polygons. We used polygons for hillside terraces because terraced hillsides are composed of several classes or land covers, including Nonlinear structures, Forest, (Likely) terraces and bunds on cropland, and Roads and bare ground; because they occur only on steep slopes; and because the horizontal distance between the individual terraces is very small, making it difficult to distinguish them from each other.

The classified terraces and bunds in raster format were vectorized using ESRI ArcScan, then their total length was calculated and compared with the digitized ground truth polylines. Classified cropland terraces and bunds were considered as correctly detected and classified if they lay within 1.5 $\mathrm{m}$ and ran parallel to the matching digitized structures. This "buffer" of $1.5 \mathrm{~m}$ was applied because the automatic classification approach may, in some cases, identify the cast shadow of a structure rather than the structure itself, depending on its layout and the position of the sun at the time the image was acquired; the outer edge of the shadow will be positioned up to $1.5 \mathrm{~m}$ away from the structure itself considering that the width of structures ranges between 0.5 and $1.5 \mathrm{~m}$. Hillside terrace polygons were compared with ground truth polygons by applying a spatial intersection. Classified hillside terrace polygons were considered as correctly classified if a majority of terraces within them were correctly classified as the respective terrace type. 


\section{Results and Discussion}

\subsection{Orthorectification and Digital Surface Model}

Due to the limited number of differentially corrected GPS points available, we had to use all of them to orthorectify the Geoeye-1 stereo data set and to generate the DSM. Consequently, we had no independent check points to assess the accuracy of the orthorectification or the DSM. But calculation of the RMSE in the $x$ - and the $y$ - direction following the bundle adjustment of the GeoEye-1 stereo pair resulted in $\mathrm{RMSE}_{\mathrm{x}}=0.24 \mathrm{~m}$ and $\mathrm{RMSE}_{\mathrm{y}}=0.13 \mathrm{~m}$. For an approximate assessment of $\mathrm{RMSE}_{\mathrm{z}}$ we compared the elevations of the differentially measured GCPs used to generate the DSM with the elevation values derived from the final DSM, resulting in an $\mathrm{RMSE}_{\mathrm{z}}$ of $1.42 \mathrm{~m}$.

\subsection{Classification of Soil and Water Conservation Structures}

An overview of the classified study area is given in Figure 5. For a more detailed assessment of the classification results we defined eight subset areas which served as ground truth areas. They were defined so that they represent the entire range and variety of SWC structures present in the study area. Within six of them (Subsets 1-6) we digitized all terraces and bunds on cropland. In the remaining two subsets (Subsets 7 and 8) we outlined all hillside terraces as polygons and subdivided them into hillside terraces with no or small trees and hillside terraces with large trees. 


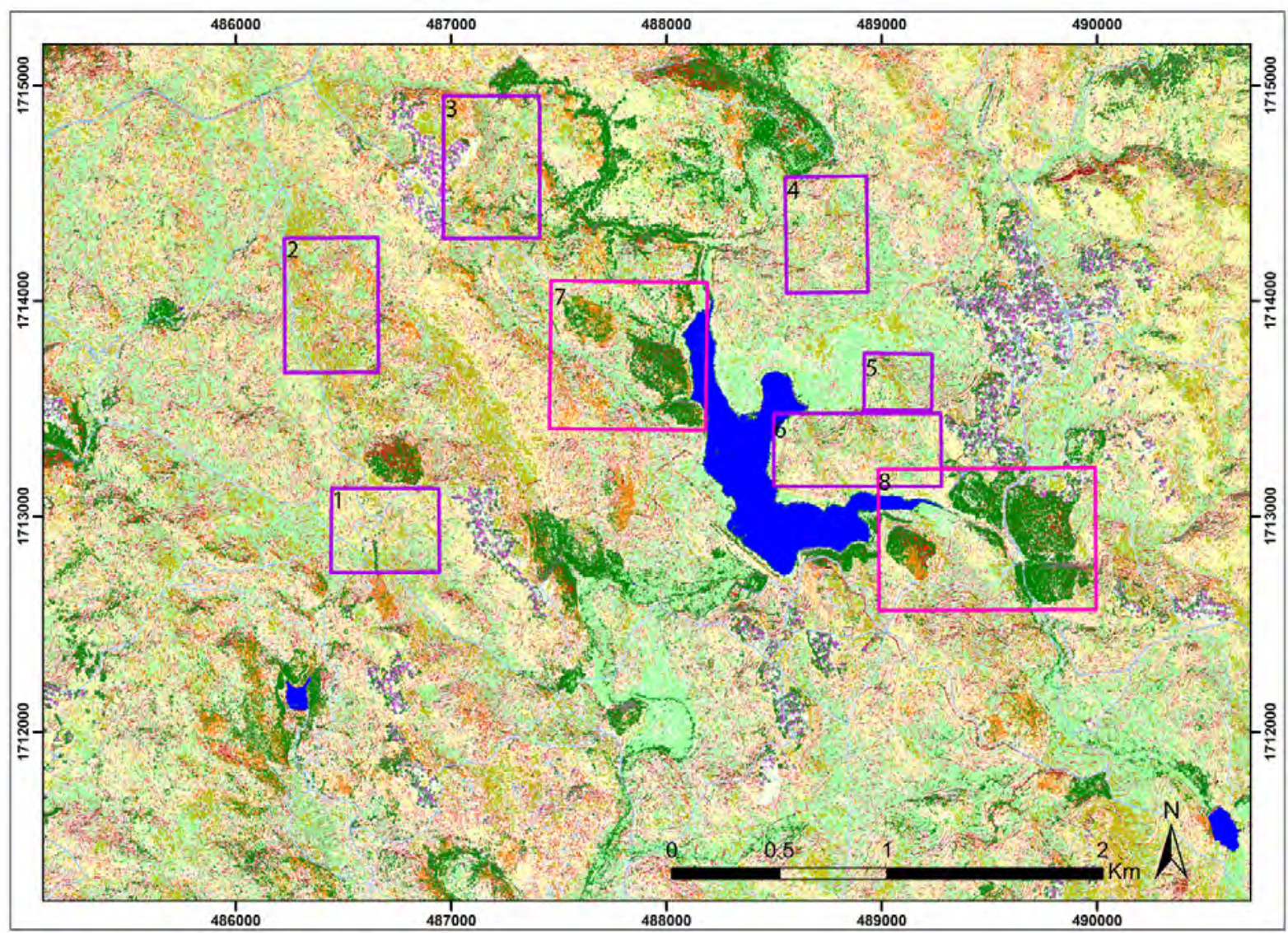

Subset areas for accuracy assessment:

$\square$ Hillside terraces $\square$ Terraces and bunds on cropland

Figure 5: Overview of Level 1 classification results across the study area. The colored boxes indicate eight subset areas that served as ground truth areas; in Subsets 1-6 all terraces and bunds on cropland were digitized, and in Subsets 7 and 8 all hillside terraces were outlined as polygons and subdivided into hillside terraces with no or small trees and hillside terraces with large trees. 

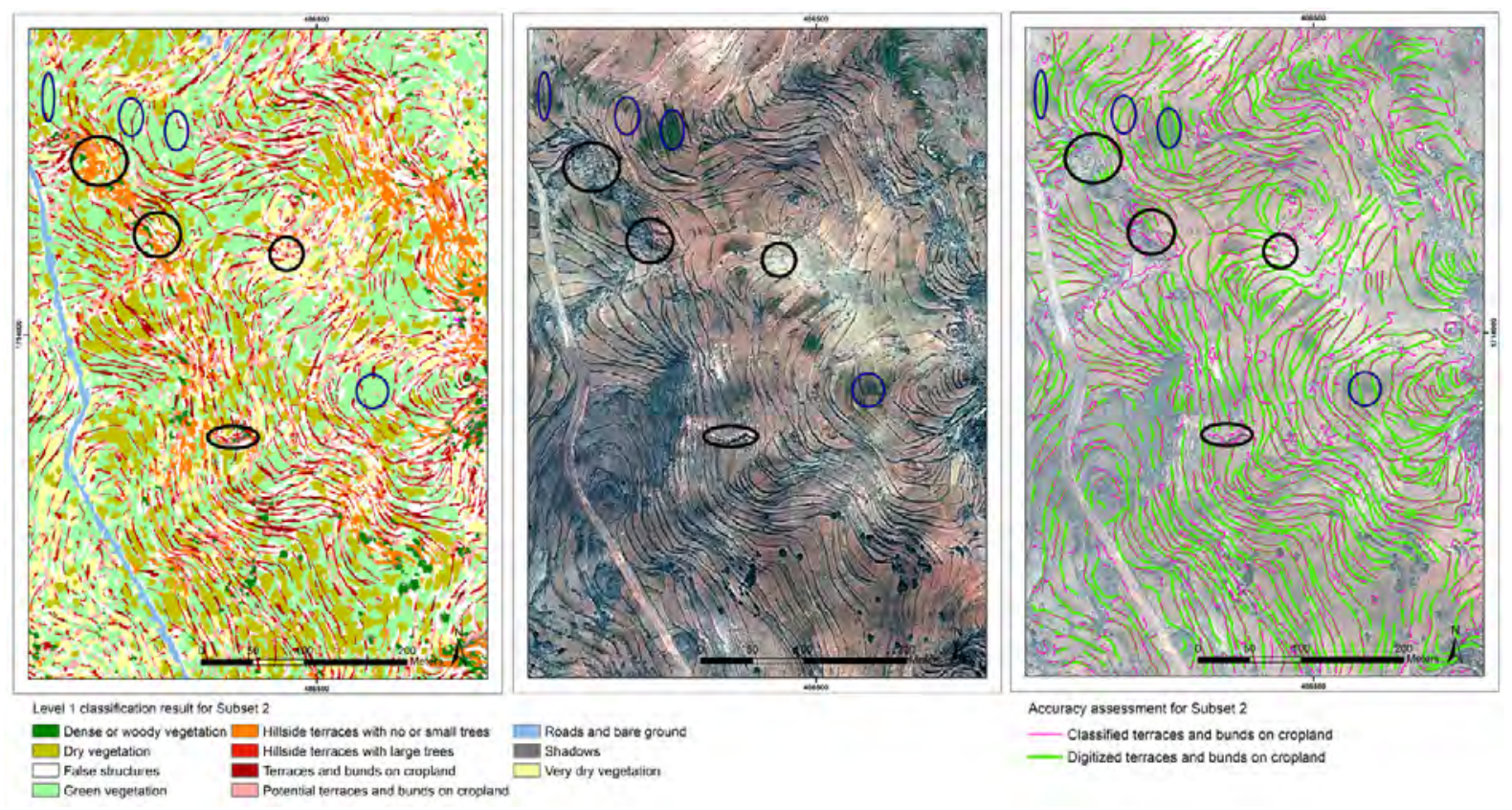

Figure 6: Subset 2. Level 1 classification result (A). Geoeoye-1 RGB color composite, in which terraces and bunds on cropland are clearly visible (B). Classified and vectorized terraces and bunds (pink, upper layer) and digitized terraces and bunds serving as ground truth (green, lower layer) (C).

Figure 6A displays the Level 1 classification result for Subset 2. It shows that the majority of clearly visible terraces and bunds on cropland were recognized as such unless there was insufficient contrast between the terrace and the surrounding fields - mostly fields covered with green vegetation (indicated by blue ellipses). In addition to Terraces and bunds on cropland, we defined a second subclass of Likely terraces and bunds on cropland. Linear image objects in this subclass either show little contrast against surrounding objects or have a more asymmetric shape than clearly classified terraces and bunds on cropland. Both subclasses were included in the vectorization process to extract linear features. As can be seen in Figure 6C, some of the lines derived from the Likely terraces and bunds on cropland class proved to be false positives. Other reasons for false positives are irregular image patterns caused by piles of straw, single trees, rock outcrops, perpendicular gullies, and nonlinearly shaped piles of rocks (indicated by black ellipses). Moreover, we also defined a class of False structures. It consists mostly of correctly classified non-linear objects that represent very dry fields. 
However, the class also contains some unrecognized terraces and bunds on cropland appearing as non-linear image objects that were not correctly delineated by the segmentation algorithm due to insufficient contrast in the satellite imagery or an insufficient difference in height in the DSM. The agricultural fields between terraces were classified as Green, Dry, or Very dry vegetation. Trees and bushes were classified as Dense or woody vegetation. Areas without vegetation cover were classified as Roads and bare ground. Furthermore, we defined classes for shadow areas, waterbodies, and buildings, as well as a correction class for erroneously classified buildings. The latter three classes are not present in Subset 2.

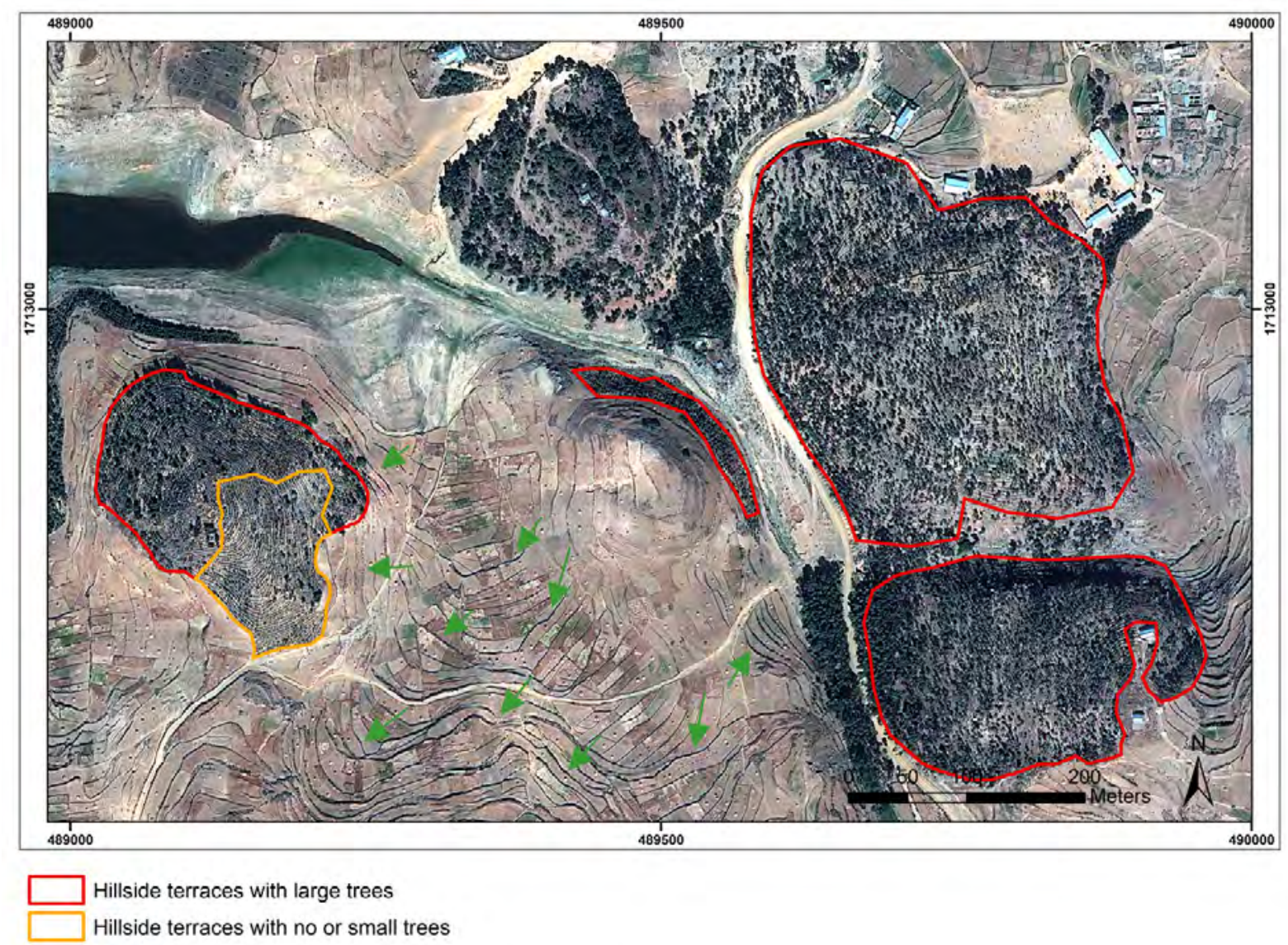

Figure 7: Geoeoye-1 RGB color composite for Subset 8, which contains three hills with afforested hillside terraces. The difference between SWC structures on cropland (brownish tone and wider distance between conservation structures, indicated by green arrows) and SWC structures on steep hills (narrow-based hillside terracing, often with forest cover) is clearly visible. 
Hillside terraces occur only on steep slopes. Most of them are afforested and almost fully covered by trees, but non-forested hillside terraces exist as well. Both types occur in Subset 8, the color composite image of which is presented in Figure 7. As can be seen in the figure, both types have a distinct visual pattern in the satellite image. This makes it possible to identify hillside terraces based on a combination of terrain and textural parameters. The differentiation between hillside terraces with no or small trees and hillside terraces with large trees was achieved in an iterative process, by analyzing the classes of neighboring segments as well as the segment classification on Level 2. Hillside terraces that were classified as Forest on Level 2 were considered Hillside terraces with large trees. Figure 8A displays the Level 1 classification result of Subset 8, while Figure 8B provides a more detailed comparison of the digitized and the classified hillside terraces. The figure shows that Hillside terraces with large trees were only classified within forested hills and match well with the digitized hillside terrace polygons, whereas Hillside terraces with no or small trees, besides being correctly classified on non-forested and terraced steep hills, were sometimes also classified in nonterraced forested areas and on fairly steep terraced cropland. Most structures classified as False structures were correctly classified as such; only a small number of them are in fact misclassified cropland terraces and bunds. 


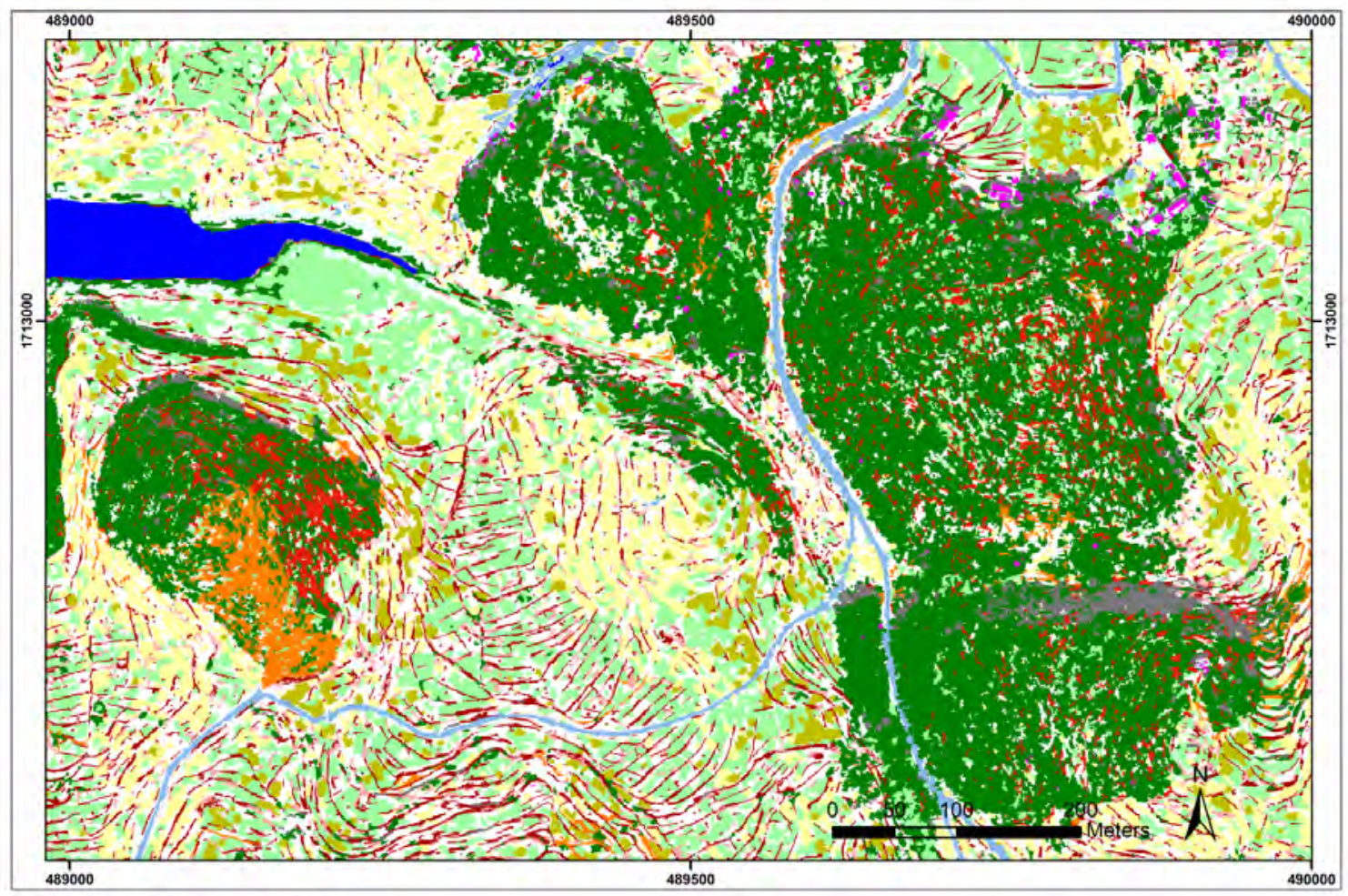

Level 1 classification result for Subset 8
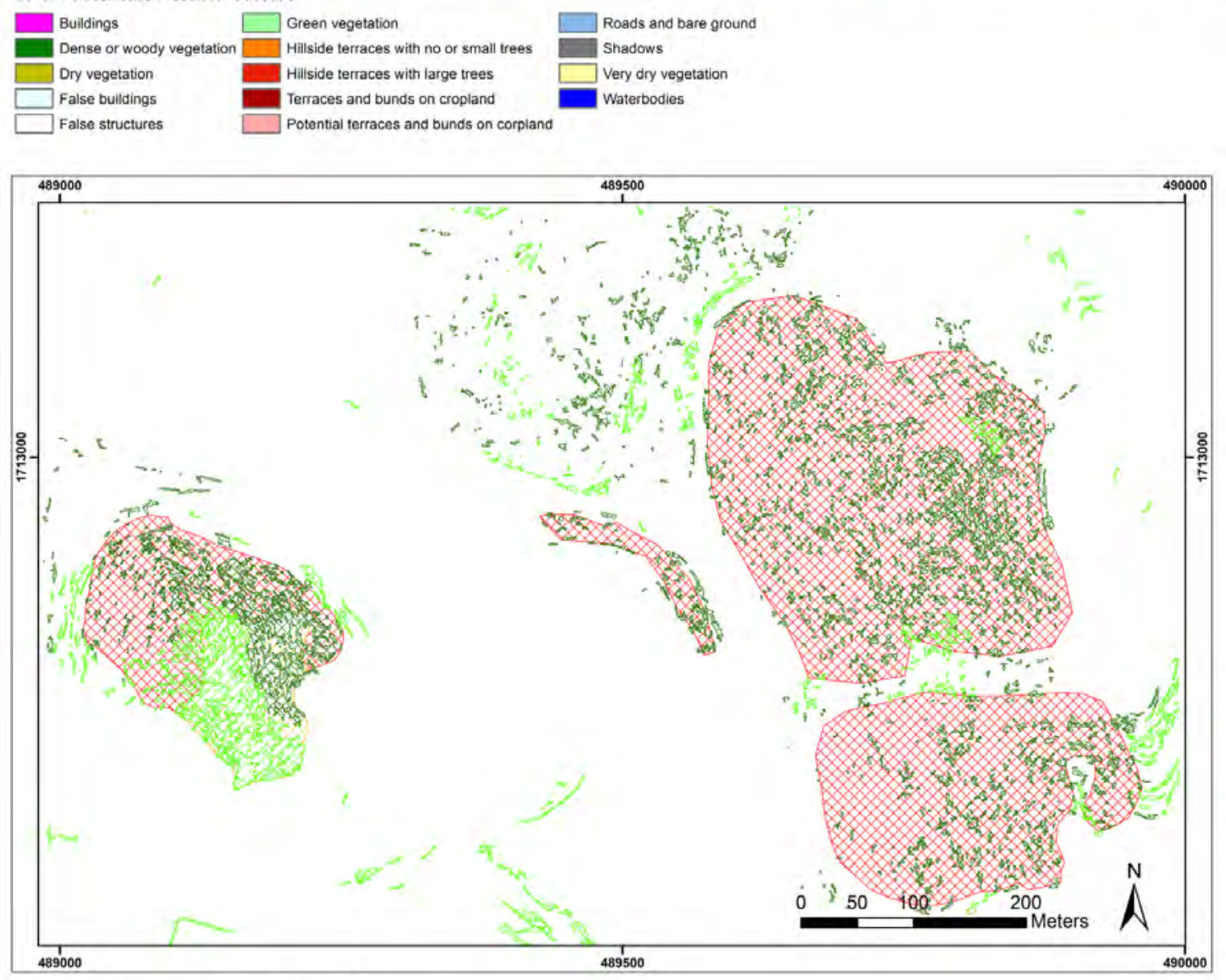

Accuracy assessment for Subset 8

Digitized hillside terraces

Hillside terraces (with higher trees - old)
Classified hillside terraces

Hillside terraces (with fewer, younger trees - young)

Hillside terraces (with fewer, younger trees - young) Hillside terraces (with higher trees - old) 
Figure 8: Level 1 classification result for Subset 8 (A). Classified hillside terraces (green and dark green, upper layer) and digitized hillside terraces serving as ground truth (red and orange, lower layer) (B).

\subsection{Accuracy Assessment}

Table 5 presents the results of the accuracy assessment. The classification results are in good visual agreement with the digitized (ground truth) SWC structures. Of the 2153 digitized linear terraces and bunds on cropland, 1689 - corresponding to 78.5\% of all digitized terraces - were detected and correctly classified. The remaining 464 terraces - corresponding to about $21.5 \%$ - were not detected at all. Most of the detected terraces were recognized only partially. Comparison of the calculated total length of all detected terraces (46,253 m) with the total length of all digitized terraces (86,401 m) shows that only $53.5 \%$ of the terrace length was detected. Furthermore, the assessment revealed a fairly large commission error. Of 3052 detected Terraces and bunds on cropland and Likely terraces and bunds on cropland (totaling a length of 61,593 m), 1679 (15,340 m) were incorrectly classified. This corresponds to about $24.9 \%$ of all classified terraces and bunds on cropland and about $18.8 \%$ of all digitized terraces and bunds on cropland (i.e. ground truth). The large number and short total length of these misclassified terraces and bunds indicates that they are rather short false positives caused by linear features within natural rock outcrops, linear features that run perpendicular to fields (such as gullies, fences, and stone walls), or livestock trails. Looking at hillside terraces, 13 of 16 digitized hillside terrace polygons were correctly classified as such (81.25\%). One polygon in each subclass was misclassified, and one area $\left(159.7 \mathrm{~m}^{2}\right)$ with non-afforested hillside terraces was not detected at all. This may be because the low amount of green vegetation on hillside terraces with small or no trees makes them harder to detect. Out of the 32,217 $\mathrm{m}^{2}$ classified as Hillside terraces with large trees, 23,006 $\mathrm{m}^{2}$ (71.4\%) were classified correctly; 3,150 m² (9.7\%) were incorrectly classified as Hillside terraces with no or small trees; and 6,060 $\mathrm{m}^{2}$ (18.8\%) were detected outside the digitized (i.e. ground truth) hillside terrace polygons, constituting a commission error. The classification accuracy for Hillside terraces with no or small trees was lower due to a larger commission error. Out 
of the total 47,581 $\mathrm{m}^{2}$ of classified Hillside terraces with no or small trees, only $23,842 \mathrm{~m}^{2}$ (50.1\%) were classified correctly; 2,901 $\mathrm{m}^{2}$ (6.1\%) were erroneously classified as Hillside terraces with large trees; and 20,838 $\mathrm{m}^{2}$ (43.8\%) were detected outside the digitized hillside terrace polygons. If we assume that hillside terraces with large trees are older than hillside terraces with small or no trees, we could say that older hillside terraces are better discriminated than more recently established nonforested hillside terraces. Like for Terraces and bunds on cropland, the large commission error can be explained by the similarity of non-forested hillside terraces with (1) terraces on steep cropland, (2) livestock trails along steep slopes, and (3) natural rock outcrops along steep slopes. All of these have similar topographic, textural, and spectral characteristics.

\begin{tabular}{|c|c|c|c|c|c|c|c|}
\hline & & \multirow[b]{3}{*}{$\begin{array}{l}\text { Ground } \\
\text { truth }\end{array}$} & \multicolumn{5}{|c|}{ Automatic classification } \\
\hline & & & \multicolumn{3}{|c|}{ Detected } & \multirow{2}{*}{$\begin{array}{l}\text { Omission } \\
\text { error (FN) }\end{array}$} & \multirow{2}{*}{$\begin{array}{c}\text { Commission error } \\
\text { (FP) }\end{array}$} \\
\hline & & & $\begin{array}{l}\text { Correctly } \\
\text { classified } \\
\text { (TP) }\end{array}$ & Misclassified & $\begin{array}{c}\text { Total } \\
\text { classified }\end{array}$ & & \\
\hline \multirow{3}{*}{$\begin{array}{c}\text { Terraces and } \\
\text { bunds on cropland }\end{array}$} & No. & 2153 & 1689 & --------** & 3052 & 464 & 1679 \\
\hline & Length (m) & 86401.7 & 46253.3 & ------** & 61593.2 & 40148.4 & 15339.9 \\
\hline & Length (\%) & 100.0 & 53.5 & --------** & 75.1 & 46.5 & 24.9 \\
\hline \multirow{2}{*}{$\begin{array}{l}\text { Hillside terraces } \\
\text { with large trees* }\end{array}$} & No. & 8 & 7 & 1 & 8 & 0 & $----{ }^{*} * *$ \\
\hline & Area $\left(m^{2}\right)$ & 206131.4 & 23006.3 & 3150.2 & 32216.8 & $0^{*}$ & 6060.3 \\
\hline \multirow{3}{*}{$\begin{array}{c}\text { Hillside terraces } \\
\text { with no or small } \\
\text { trees* }\end{array}$} & No. & 8 & 6 & 1 & 7 & 1 & $----* * *$ \\
\hline & Area $\left(m^{2}\right)$ & 72827.5 & 23842.1 & 2901.4 & 47581.3 & $159.7^{*}$ & 20837.8 \\
\hline & \multicolumn{7}{|c|}{$\begin{array}{l}\text { * The digitized polygons of hillside terraces consist of several classes such as trees, likely terraces and bunds, terraces } \\
\text { and bunds on cropland, etc. The omission error here represents the area of the polygons that were not detected at all. } \\
\text { For misclassifications of digitized hillside terrace polygons see column "Misclassified". } \\
\text { ** There are no incorrectly classified lines as there are only recognized or incorrectly recognized terraces and bunds } \\
\text { (commission error). } \\
\text { *** Not analyzed, since number of polygons is irrelevant. }\end{array}$} \\
\hline
\end{tabular}

Table 5: Accuracy assessment for the total number and length $(\mathrm{m})$ or extent $\left(\mathrm{m}^{2}\right)$ of terraces and bunds on cropland and hillside terrace polygons detected and classified in the eight subsets. Correctly classified objects are also referred to as true positive (TP), the commission error as false positive (FP), and the omission error - in this case, all unrecognized terraces - as false negative (FN). 
Unfortunately, many papers provide a qualitative accuracy assessment based on visual inspection rather than reporting accuracy statistics (Sheeren et al. 2009; Tansey et al. 2009; Karydas et al. 2005). This is likely due to the lack of an optimal method for assessing the accuracy of linear feature classifications (Quackenbush, 2004). Consequently, there are not many studies with which we can compare our accuracy results. Bailly and Levavasseur (2012) tested a line segment detector (Grompone von Gioi et al. 2012) for the detection of terrace walls in a simulated VHR optical Pleiades-like 3D scene from LiDAR and stereo photogrammetric airborne digital terrain and digital surface models with a $1.0 \mathrm{~m}$ spatial resolution. They reported their detection (true positive, TP) and commission (false positive, FP) rates as a percentage of the reference cumulated length of linear elements. For the three methods they had tested the TP rates ranged between 53 and $86 \%$ and the FP rates between 18 and 38\%. Omission (false negative, FN) rates were only specified for one test (FN = 14\%). Diaz-Varela et al. (2014) applied a multiscale OBIA approach to classify terraces in an orthoimage and digital surface model, both with a $0.11 \mathrm{~m}$ spatial resolution and acquired by a UAV. Out of 136 terraces they correctly detected 102 terraces, corresponding to a TP rate of 75\%. They obtained an FP rate of $12 \%$ and a FN rate of $25 \%$. The reported accuracies of these two studies are similar to the results we obtained for terraces and bunds on cropland, with a TP rate of $78 \%$ (number of correctly classified terraces) and the corresponding FN rate of 22\%. Our accuracies are also similar to those achieved in the above studies when looking at the detection and commission rates as a percentage of the reference cumulated length of linear elements, where our approach achieved a TP rate of $54 \%$ and an $\mathrm{FP}$ rate of $25 \%$.

\subsection{Estimation of Terraces and Bunds Constructed in the Study Area}

The six subsets in which ground truth for Terraces and bunds on cropland was digitized cover a total area of $1,310,651.6 \mathrm{~m}^{2}$. Within this area, digitization led to the identification of a total of $86,401.7 \mathrm{~m}$ of terraces and bunds (ground truth), whereas the automatic classification of these structures produced a total of $61,593 \mathrm{~m}$ (71.3\% of total length of digitized linear structures). This results in an average of 
$0.06593 \mathrm{~m}$ of implemented cropland terraces and bunds per $\mathrm{m}^{2}$ of ground truth subset area based on the digitization, and $0.04699 \mathrm{~m}$ of implemented cropland terraces and bunds per $\mathrm{m}^{2}$ of ground truth subset area estimated based on the classification result.

For the entire study area covering 23,335,976 $\mathrm{m}^{2}$, our classification indicated a total of 831,002 $\mathrm{m}$ of terraces and bunds on cropland $\left(0.03561 \mathrm{~m} / \mathrm{m}^{2}\right)$. Digitizing SWC structures throughout the entire study area would have exceeded the scope of this study; therefore, we have no detailed ground truth quantification of SWC structures implemented throughout the area. If we upscale the digitized ground truth to the entire study area, assuming that the density of SWC structures in the entire study area is similar to that identified by digitization in the subset areas $\left(0.06593 \mathrm{~m} / \mathrm{m}^{2}\right)$, this results in an estimated ground truth of approximately 1,538,370 m of terraces and bunds on cropland.

The estimation of implemented SWC structures can also be extrapolated to the study area based on the densities of classified SWC structures. Considering the two densities obtained for the ground truth subsets and the entire study area $\left(\varnothing=0.0413 \mathrm{~m} / \mathrm{m}^{2}\right)$, their standard error $\left( \pm 0.0057 \mathrm{~m} / \mathrm{m}^{2}\right)$, and the assessed omission error of $28.7 \%$, our classification approach provides an estimate of 1,165,490 m to $1,537,949 \mathrm{~m}$ of terraces and bunds on cropland implemented in the study area. The upper limit of this range is close to the estimate based on the density of digitized SWC structures in the ground truth subsets.

No matter which of the above figures is closest to the reality on the ground, they all document the substantial efforts made to conserve soil and water resources in the study area, particularly over the past 40 years, and even more particularly in the past two decades, that is, since the country's independence in 1993. The number of implemented terraces and bunds represents hundreds of thousands of person-days invested in the construction of SWC structures. Assuming that one person builds an average $5 \mathrm{~m}$ of terraces or bunds per day - a value that appears more realistic, given the good quality of work, than the rule-of-thumb value used by the Ministry of Agriculture (8-10 m per person per day) - the construction of the 1,538,370 m of cropland terraces and bunds estimated based on our ground truth data involved around 300,000 person-days. Even at the faster pace used by the Ministry of Agriculture, the work would still have involved 150,000-190,000 person-days. These 
figures relate only to conservation structures in cropland (terraces and soil bunds), without hillside terracing. Unfortunately, no reliable recent figures are available regarding the monetary costs of such an effort, but in another area that is similarly well-conserved as our study area, the costs of SWC per hectare were estimated at about USD 450 per hectare in 2001 (Juel 2002). Taking this figure, the conservation work done on our study area's cropland (2,333 ha) would represent a value of USD 1,050,000. It should be noted that our study area makes up only a small fraction of Eritrea's Highlands. Unfortunately, we found no reliable figures regarding the extent of cropland in the entire Highlands, so we cannot provide a cost estimate for full area conservation throughout the Highlands in terms of labor or money.

\subsection{Transferability and Input Data Requirements}

With some adjustments, the methodology presented in this paper can be transferred to a larger or a different area to detect the same types of SWC structures, provided that the land cover, land use, and topography of this area are similar to our study area and that the SWC structures have similar spectral characteristics in the satellite images used. Thresholds will need to be adjusted in the working steps on the two segmentation levels, and during the recursive classification refinements. The more land cover and land use in the new study area differ from the those in the area studied here, the more adjustments will need to be made to the definitions and class hierarchy. Minimum requirements of the input data include (1) a horizontal resolution of at least $0.5 \mathrm{~m}$, (2) coverage of the electromagnetic spectrum from blue to near-infrared or wider, and (3) a DSM with a minimum horizontal resolution of $1.0 \mathrm{~m}$ and a vertical resolution that enables clear identification of SWC structures (e.g. $<0.5 \mathrm{~m}$ for terraces with a height of $0.5 \mathrm{~m}$ ). The images should preferably have been acquired at a time when contrasts between SWC structures and the surrounding agricultural fields are highest. In the case of Eritrea, this is during the dry season, when green vegetation is sparse. Moreover, a low sun elevation angle might be helpful in identifying terraces and higher bunds because it increases cast shadow effects and thus contrast. 


\section{Conclusions and Future Research}

Over the past few decades, government authorities, non-government organizations, and individual farmers have made major efforts to implement SWC structures in Eritrea in order to counteract soil erosion and combat land degradation, thereby securing important ecosystem services. Until now, there was little reliable quantitative and very little spatial information about the distribution and extent of the SWC structures implemented. Furthermore, the current condition of these structures is unknown due to the absence of a reliable monitoring system.

The aim of this study was, therefore, to assess the potential of a set of VHR stereo Geoeye- 1 satellite data combined with a detailed DSM derived from that data set for identifying, differentiating, and quantifying the most widespread types of SWC structures present in Eritrea. The study results lead us to the following conclusions:

- The very high geometric resolution of $0.5 \mathrm{~m}$ and the four spectral bands of Geoeye-1 (blue, green, red, near-infrared), as well as the derived DSM with a horizontal resolution of $1.0 \mathrm{~m}$ and a vertical resolution that captured the heights of most cropland terraces and bunds in the study area, proved to be suitable and can be considered to fulfil the minimum requirements. The terrain, texture, and Canny edge-filtered layers that were derived from the Geoeye- 1 data and used as additional input proved to add important information. However, a similar study done on the basis of 0.11-m UAV orthoimages provided even more detailed and accurate results, indicating that use of UAVs might be a future option for providing up-to-date lowcost orthoimages and digital surface models for terrace monitoring across fairly small areas.

- We were successful in achieving our aims taking an object-based classification approach. We developed a suitable iterative rule-set on two object scales, with rules based mainly on spectral, textural, shape, and topographic properties, and integrating neighboring-object, super-object, and sub-object relationships. The combination of an SVM classification algorithm and refinement based on membership functions worked well and successfully assigned all objects to one of the land cover or land use classes defined for the study area. The approach enabled us to identify and separate from other classes the majority (1,689 out of 
2,153; 78.5\%) of terraces and bunds, as well as most areas with hillside terraces (13 of 16 digitized polygons correctly classified as such; 81,25\%). By integrating a second, coarser level of landscape zone classifications, we succeeded in further subdividing hillside terraces into Hillside terraces with no or small trees and Hillside terraces with large trees. We achieved an acceptable classification accuracy that is in line with the accuracies obtained in two comparable studies (Bailly and Levavasseur, 2012; Diaz-Varela et al. 2014), except for a large commission error for non-afforested hillside terraces. This large error is due to the fact that these terraces' spectral, textural, and shape properties can be similar to those of other objects on steep slopes, such as rock outcrops, livestock trails, and terraces built at a short horizontal distance of each other.

- The accuracy assessment also showed that terraces and bunds on cropland tend to be extracted only partially, leading to a large omission error (FN rate) in terms of length (47\%), even though the omission error in terms of the number of lines is much smaller (22\%). By contrast, the commission error (FP rate) in terms of length is acceptable (19\%, or 15,340 m out of 86,402 m). This commission error is slightly higher from a user accuracy perspective (25\%, or $15,340 \mathrm{~m}$ out of $61,593 \mathrm{~m})$.

- Based on our ground truth data, we estimate that approximately $1,538,370 \mathrm{~m}$ of cropland terraces and bunds were implemented on cropland in the study area. Our classification leads to estimates ranging from $1,165,490 \mathrm{~m}$ to $1,537,949 \mathrm{~m}$. The upper limit is thus close to the ground-truth-based approximation. Taking the latter as a basis, we estimate that the construction of these conservation structures involved over 300,000 person-days of work for as limited an area as $23 \mathrm{~km}^{2}$.

Our approach has potential for application in other areas worldwide that have similar ecological conditions - especially in drylands - to assess and monitor the extent of existing SWC structures and identify conservation gaps that threaten the sustainability of land management. The increasing availability of technologies enabling the generation of very detailed and accurate DSMs, such as laser scanning from aircraft or UAV-based aerial photography, will expand the potential of SWC structure identification. However, these technologies require accessibility and flight authorization by the 
country in which the survey is to take place. Furthermore, the increasing availability of big data is encouraging the development of new promising learning approaches and algorithms - such as weaklysupervised object detection or deep-learning-based feature representation (Cheng and Hang, 2016) which will further advance the detection of objects and linear features. For the time being, our research will focus on the transferability of our methodology to the entire Highlands of Eritrea.

\section{Acknowledgements}

The authors acknowledge support from the former Soil Conservation Research Programme (SCRP) and the former Eastern and Southern Africa Partnership Programme (ESAPP), both funded by the Swiss Agency for Development and Cooperation (SDC). Further financial support was provided by the Syngenta Foundation for Sustainable Agriculture. The paper benefitted from helpful comments by Dr. Karl Herweg, who coordinated the SCRP in the 1970s and 1980s. Study design, execution, analysis, article writing and the decision to publish it were performed by the authors, and funders had no such involvement.

\section{References}

Agnoletti, M., Cargnello, G., Gardin, L., Santoro, A., Bazzoffi, P., Sansone, L., Pezza, L., Belfiore, N. 2011. Traditional landscape and rural development: comparative study in three terraced areas in northern, central and southern Italy to evaluate the efficacy of GAEC standard 4.4 of cross compliance. Italian J. Agron. 6, 121-139.

Aksoy, S., Akçay, H.G., Wassenaar, T. 2010. Automatic mapping of linear woody vegetation features in agricultural landscapes using very high resolution imagery. IEEE Transact. Geosci. Remote Sens. 48, 511-522.

Andrini, D. 2011. Erfassung von linearen Bodenkonservierungsstrukturen mit Hilfe von Satellitendaten und objektorientierter Klassifikation im zentralen Hochland von Eritrea. Master Thesis, University of Bern, Bern, Switzerland. 
Baatz, M., Schäpe, M. 2000. Multiresolution segmentation - An optimization approach for high quality multi-scale image segmentation. In: J. Strobl, T.Blaschke, G. Griesebner (Eds.), Angewandte Geographische Informations-Verarbeitung XII, Wichmann Verlag, Karslruhe, pp. 12-23.

Bailly, J.-S., Levavasseur, F. 2012. Potential of linear features detection in a Mediterranean landscape from 3D VHR optical data: application to terrace walls. In: Geoscience and Remote Sensing Symposium (IGARSS), 2012 IEEE International.

Benz, U.C., Hofmann, P., Willhauck, G., Lingenfelder, I., Heynen, M. 2004. Multiresolution, objectoriented fuzzy analysis of remote sensing data for GIS-ready information. ISPRS J. Photogr. Remote Sens. 58, 239-258.

Blaschke, T., Lang, S., Lorup, E., Strobl, J., Zeil, P. 2000. Object-oriented image processing in an integrated GIS/remote sensing environment and perspectives for environmental applications. In: A. Cremers, K.Greve (Eds.), Environmental Information for Planning, Politics and the Public. Vol. 2. Metropolis Verlag, Marburg, pp. 555-570.

Blaschke, T., Strobl, J. 2001. What’s wrong with pixels? Some recent developments interfacing remote sensing and GIS. GeoBIT/GIS, 6, 12-17.

Blaschke, T., Burnett, C., Pekkarinen, A. 2004. New contextual approaches using image segmentation for object-based classification. In: De Meer F., de Jong S., (Eds.), Remote Sensing Image Analysis: Including the spatial domain. Kluver Academic Publishers; Dordrecht, pp. 211-236.

Blaschke, T., Lang, S., Hay, G.J. 2008. Object Based Image Analysis. Springer, Heidelberg, Berlin, New York, p. 817.

Blaschke T. 2010. Object-based image analysis for remote sensing. ISPRS Int. J. Photogramm., 65, 216.

Boerma, P. 2006. Assessing Forest Cover Change in Eritrea—A Historical Perspective. Mt. Res. Dev. 26, 41-47.

Bojö, J. 1995. World Bank Working Paper 1: Land degradation and Rehabilitation in Eritrea. Washington D.C. World Bank. 
Bosshart U. 1997. Measurement of river discharge for the SCRP research catchments: gauging station profiles. Soil Conservation Research Programme, Research Report 31, University of Berne, Switzerland.

Canny, J. 1986. A computational approach to edge detection. IEEE T. Pattern Anal. 8, 679-714. Chen, G. Han, J. 2016. A survey on object detection in optical remote sensing images. ISPRS J. Photogramm. 117, 11-28.

Das, S., Mirnalinee, T., Varghese, K. 2011. Use of salient features for the design of a multistage framework to extract roads from high-resolution multispectral satellite images. IEEE Trans. Geosci. Remote Sens. 49, 3906-3931.

Diaz-Varela, R.A., Zarco-Tejada, P.J., Angileri, V., Loudjani, P. 2014. Automatic identification of agricultural terraces through object-oriented analysis of very high resolution DSMs and multispectral imagery obtained from an unmanned aerial vehicle. Journal Environ. Manage.134, 117-126.

Duro, D.C., Franklin, S.E., Dubé, M.G. 2012. A comparison of pixel-based and object-based image analysis with selected machine learning algorithms for the classification of agricultural landscapes using SPOT-5 HRG imagery. Remote Sens. Env. 118, 259-272

FAO 1998. World Reference Base for Soil Resources. FAO, Rome.

Flanders, D., Hall-Beyer, M., Pereverzoff, J. 2003. Preliminary evaluation of eCognition object-based software for cut block delineation and feature extraction. Can. J. Remote Sens., 29, 441-452.

Gosh, A., Joshi, P.K. 2014. A comparison of selected classification algorithms for mapping bamboo patches in lower Gangetic plains using very high resolution WorldView 2 imagery. Int.J. Appl. Earth Obs.26, 298-311.

Grompone von Gioi, R., Jakubowicz, J., Morel J.-M., Randall, G. 2012. LSD: A Fast Line Segment Detector with a False Detection Control. IEEE Trans. Pattern Anal. Mach. Intell. 32, 722-732. 
Gurtner, M., Zewenghel, G., Iyassu, H., Zerai, T., Hadgu, Y., Stillhardt, B., Roden, P. 2006. Land Management in the Central Highlands of Eritrea. SLM Report 6. Bern, Geographica Bernensia. ISBN 978-3-906151-90-2

Haralick, R.M., Shanmugan, K., Dinstein, I. 1973. Textural Features for Image Classification. IEEE Trans. Syst., Man, and Cybern. 3, 610-621.

Herweg, K., Ludi, E. 1999. The performance of selected soil and water conservation measures - case studies from Ethiopia and Eritrea. Catena. 36, 99-114.

Hay G.J., Marceau D., Dube P., Bouchard A. 2001. A multiscale framework for landscape analysis: Object-specific analysis and upscaling. Landscape Ecol. 16, 471-490.Hurni, H. 1978. Soil erosion forms in the Simen mountains - Ethiopia (with map 1:25'000). Geographica Bernensia, G8, 93-100. Huang, X., Zhang, L. 2009. Road centreline extraction from high-resolution imagery based on multiscale structural features and support vector machines. Int. J. Remote Sens. 30, 1977-1987.

Hurni, H. 1987. Erosion - productivity - conservation systems in Ethiopia. In Pla Sentis, I. (Eds.), Soil Conservation and Productivity. Proceedings of the 4th Int. Soil Conservation Conference, Maracay, Venezuela, pp. 654-674.

Hurni, H. 1990. Degradation and Conservation of Soil Resources in the Ethiopian Highlands. In: Messerli, B, Hurni H. (Eds.), African Mountains and Highlands: Problems and Perspectives. African Mountain Association (AMA), Maerceline, Missouri, pp. 51-63.

Hurni, H. 1993. Land degradation, famine, and land resource scenarios in Ethiopia. National Conference on a Disaster Prevention and Preparedness Strategy for Ethiopia, December 5-8. Addis Abeba. In: Pimentel, D. (Eds.), World Soil Erosion and Conservation. Cambridge University Press, Cambridge, pp. 27-61.

Heinzel, J., Koch, B. 2012. Investigating multiple data sources for tree species classification in temperate forest and use for single tree delineation. Int.J. Appl. Earth Obs. 18, 101-110. 
Juel, M. 2002. Watershed Development: Economic and Institutional Sustainability of Integrated Watershed Development at Community Level - Evidence from Case Studies. Proceedings of 4th International DANIDA Workshop on Watershed Development, Asmara, Eritrea November 2001. Karydas, C.G., Sekuloska, T., Sarakiotis, I., 2005. Fine scale mapping of agricultural landscape features to be used in environmental risk assessment in an olive cultivation area. IASME Trans. 4, 582-589.

Kaszta, Z., Van De Kerchove, R., Ramoelo, A., Cho, M.A., Madonsela, S., Mathieu, R., Wolff, E. 2016. Seasonal Separation of African Savanna Components Using Worldview-2 Imagery: A Comparison of Pixel- and Object-Based Approaches and Selected Classification Algorithms. Remote Sens. 8, 763-782.

McNab, W.H. 1989. Terrain shape index: quantifying effect of minor landforms on tree height. For. Sci. 35, 91-104.

Mekuriaw, A., Heinimann, A., Zeleke, G., Hurni, H., Hurni, K. 2017. An automated method for mapping physical soil and water conservation structures on cultivated land using GIS and Remote Sensing techniques. J. Geogr. Sci.27, 79-94.

Negassi, A., Bein, E., Ghebru, K., Tengnäs, B. 2002. Soil and Water Conservation Manual for Eritrea. Regional Land Management Unit (RELMA); Swedish International Development Cooperation Agency (SIDA). ISBN 9966-896-65-1

NEMP-E 1995. National Environmental Management Plan for Eritrea, 1995. Prepared by the Government of Eritrea for the People of Eritrea. Eritrean Agency for the Environment, Asmara. Nyssen, J., Haile, M., Naudts, J., Munro, N., Poesen, J., Moeyersons, J. Frankl., A., Deckers, J., Pankhurst, R. 2009. Desertification? Northern Ethiopia re-photographed after 140 years. Sci. Total Env. 407, 2749-2755.

Ogbazghi, W., Stillhardt, B., Herweg, K. 2011. Sustainable Land Management. A textbook with a focus on Eritrea. Geographica Bernensia Bern, and Hamelmalo Agricultural College, Keren. ISBN 978-3-605-835-24-3. 
PCI Geomatics 2014. PCI Geomatica Online Help, Version 2015, PCI Inc, Ontario, Canada.

Pesaresi, M., Gerhardinger, A., Kayitakire, F. 2008. A robust built-up area presence index by anisotropic rotation-invariant textural measure. IEEE J. Sel. Top. Appl. 1, 180-192.

Petropoulos, G.P., Kalaitzidis, C., Vadrevu, P.K. 2012. Support vector machines and object-based classification for obtaining land-use/cover cartography from Hyperion hyperspectral imagery.

Comput. Geosci., 41, 99-107.

Quackenbush, L.J. 2004. A review of techniques for extracting linear features from imagery.

Photogramm. Eng. Remote Sens., 70, 1383-1392.

Rouse, J.W., Haas, R.H., Schell, J.A., Deering, D.W. 1973. Monitoring vegetation systems in the Great Plains with ERTS. In: Third ERTS Symposium, NASA SP-351. NASA: Washington, DC., USA, 1, 309-317.

Schwilch, G., Hessel, R., Verzandvoort, S. 2012. Desire for Greener Land. Options for Sustainable Land Management in Drylands. Bern, Switzerland, and Wageningen, The Netherlands: University of Bern - CDE; Alterra - Wageningen UR;, ISRIC - World Soil Information; and CTA - Technical Centre for Agriculture and Rural Cooperation. ISBN 978-94-6173-329-0

Sheeren, D., Bastin, N., Ouin, A., Ladet, S., Balent, G., Lacombe, J.P. 2009. Discriminating small wooded elements in rural landscape from aerial photography: a hybrid pixel/object-based analysis approach. Int. J. Remote Sens. 30, 4979-4990.

Song, M., Civco, D. 2004. Road extraction using SVM and image segmentation. Photogramm. Eng. Remote Sens. 70, 1365-1371.

Stillhardt, B., Herweg, K., Hurni, H. 2002. Long-term Monitoring of Soil Erosion and Soil and Water Conservation in Afdeyu, Eritrea (1984-1998). Soil Erosion and Soil and Water Conservation Database. Centre for Development and Environment University of Bern; Department of Agricultural Research and Human Resource Development, Ministry of Agriculture, Government of Eritrea; University of Asmara College of Agriculture; Syngenta Foundation for Sustainable Agriculture; and Vision Eritrea. ISBN 3-906151-60-3 
Tansey, K., Chambers, I., Anstee, A., Denniss, A., Lamb, A. 2009. Object-oriented classification of very high resolution airborne imagery for the extraction of hedgerows and field margin cover in agricultural areas. Appl. Geogr. 29, 145-157.

UNCCD 2014. The Land in Numbers. Livelihoods at a Tipping Point. Secretariat of the United Nations Convention to Combat Desertification. Bonn, Germany.

Vapnik, V.N. 2000. The Nature of Statistical Learning Theory; Springer, New York.

WOCAT 2007. Where the land is greener. Case studies and analysis of soil and water conservation initiatives worldwide. Editors: Hanspeter Liniger and William Critchley. Co-published by CTA, FAO, UNEP and CDE.. ISBN 978-92-9081-339-2.

Wang W., Yang, N., Zhang, Y. Wang, F., Cao, T., Eklund, P. 2016. A review of road extraction from remote sensing images. J. Traffic Transp. Eng. (English Edition). 3, 271-282.

Woldetensae T., Dessalegn, B., Burtschner, R., Woldemichael, B., Gassner M., Stillhardt, B., Kohler, T. 2005. Amadir - Livelihood and Resource Management in an Eritrean Highland Community.

Geographica Bernensia, Bern. ISBN 3-906151-85-9.

Zeug, G., Eckert, S. 2010. Population Growth and Its Expression in Spatial Built-up Patterns: The Sana’a Yemen Case Study. Remote Sens. 2, 1014-1034. 